\title{
Tinjauan Orientasi Efektivitas Rencana Pengelolaan Program Kawasan Konservasi Kementerian Kelautan dan Perikanan
}

\author{
Arisetiarso Soemodinoto $^{1}$, Andi Rusandi ${ }^{2}$ dan Amehr Hakim ${ }^{3}$
}

1.Integrated Conservation and Development Planning Consultant, Bandung, Indonesia

2. Direktorat Konservasi \& Keanekaragaman Hayati Laut, Kementerian Kelautan dan Perikanan, Jakarta, Indonesia

3. Direktorat Konservasi \& Keanekaragaman Hayati Laut, Kementerian Kelautan dan Perikanan, Jakarta, Indonesia

Korespondensi: ari.soemodinoto@gmail.com

DOI: doi.org/10.47266/bwp.v4i1.81| halaman: 106-138

Dikirim: 10-08-2020 | Diterima: 18-03-2021 | Dipublikasikan: 31-03-2021

\begin{abstract}
Abstrak
Pengelolaan yang efektif telah menjadi bagian tak terpisahkan dari upaya menangani masalah 'kawasan konservasi kertas', sekaligus untuk memfasilitasi pembangkitan manfaat-manfaat ekologi dan sosial-ekonomi kawasan konservasi laut. Agar dapat dikelola secara efektif setiap kawasan konservasi laut wajib dilengkapi dengan rencana pengelolaan (RP) berorientasi efektivitas pengelolaan. Makalah ini menyajikan persyaratan yang harus dipenuhi sebuah RP agar ia layak disebut berorientasi efektivitas pengelolaan, yaitu: (1) daftar keanekaragaman dan sumberdaya hayati terbarukan yang terancam oleh kegiatan manusia; (2) kegiatankegiatan manusia yang secara langsung maupun tak-langsung mengancam keberlanjutan keanekaragaman dan sumberdaya hayati; (3) strategi untuk menangani kegiatan-kegiatan manusia yang mengancam keanekaragaman dan sumberdaya hayati; dan (4) tujuan dan sasaran pengelolaan kawasan yang dinyatakan dengan jelas dan terukur. Untuk contoh, persyaratan diterapkan pada rencana pengelolaan dan zonasi (RPZ) salah satu kawasan konservasi perairan, pesisir dan pulau-pulau kecil yang berada di bawah yurisdiksi Kementerian Kelautan dan Perikanan, yaitu Taman Wisata Perairan (TWP) Gili Matra. Selain menyarankan isi dan cara menyusun RP berorientasi efektivitas pengelolaan, makalah ini juga sangat menyarankan agar semua RP yang sudah ada ditinjau-ulang dan direvisi agar berorientasi efektivitas pengelolaan.
\end{abstract}

Kata kunci: pengelolaan kawasan konservasi, efektivitas pengelolaan, standar terbuka untuk praktik konservasi, hubungan pengelolaan dan zonasi, kelautan dan perikanan 


\title{
Tinjauan Orientasi Efektifitas Rencana Pengelolaan Program Kawasan Konservasi Laut Kementerian Kelautan dan Perikanan
}

\author{
Arisetiarso Soemodinoto, Andi Rusandi dan Amehr Hakim
}

\section{Pendahuluan}

"Efektivitas Pengelolaan" (management effectiveness) menjadi kata kunci bagi upaya pengembangan dan pengelolaan kawasan konservasi baik di lingkungan darat maupun laut. Didefinisikan sebagai "tingkat sejauh mana upaya pengelolaan mencapai tujuan dan sasaran (yang dinyatakan di dalam dokumen rencana pengelolaan)" (Hockings et al., 2000, 2006), efektivitas pengelolaan dinyatakan secara eksplisit pada Target Keanekaragaman Hayati Aichi 11 yang menjadi acuan utama bagi pendirian, pengembangan dan pengelolaan kawasan-kawasan konservasi sejagad. Target tersebut menyatakan bahwa pada tahun 2020, paling tidak 17 persen wilayah daratan dan perairan darat, dan 10 persen wilayah pesisir dan laut, khususnya yang memiliki nilai penting bagi keanekaragaman hayati dan jasa-jasa ekosistem, dikonservasi melalui sistem-sistem kawasan pelindungan yang terkoneksi dengan baik dan secara ekologi terwakili, dan melalui upaya konservasi berbasis-kawasan lainnya, yang dikelola secara efektif dan adil, dan terintegrasi dengan bentang-alam dan bentang-laut yang lebih luas".

Indonesia, sebagai salah satu negara yang meratifikasi Konvensi Keanekaragaman Hayati melalui Undang-Undang Nomor 5 Tahun 1994 tentang Pengesahan United Nations Convention on Biological Diversity (Konvensi Perserikatan Bangsa-Bangsa mengenai Keanekaragaman Hayati), telah berkomitmen untuk mencapai Target 11 tersebut (Soemodinoto et al., 2018). Sejauh ini, Indonesia telah mendirikan beragam jenis kawasan konservasi laut yang secara kolektif lebih dikenal dengan sebutan kawasan konservasi perairan, pesisir dan pulau-pulau kecil (KKP3K), sebanyak 197 buah dengan luas keseluruhan mencapai 23,4 juta hektare atau sekitar 7,1\% dari perairan pesisir dan laut Indonesia (Rusandi, 2020). Dari 167 kawasan konservasi yang berada di bawah yurisdiksi Kementerian Kelautan dan Perikanan, dan pemerintah daerah/provinsi, baru 24 kawasan atau sekitar 14\% yang telah mencapai peringkat dikelola secara minimum (3-hijau) menurut kriteria Pedoman Teknis Evaluasi Efektivitas Pengelolaan Kawasan Konservasi Perairan, Pesisir dan Pulau-Pulau Kecil (Rusandi, 2020).

Belum adanya kawasan konservasi yang telah dikelola secara optimum (atau berada di peringkat 4, masuk katagori 'biru' menurut Pedoman Teknis E-KKP3K) menyarankan perlunya mencari jalan untuk meningkatkan peringkat efektivitas pengelolaan semua kawasan konservasi laut ke tingkat lebih tinggi. Salah satu cara yang paling mungkin adalah dengan mendorong semua kawasan konservasi laut untuk memiliki rencana pengelolaan (RP) berorientasi efektivitas pengelolaan, seperti yang disarankan oleh para pakar (antara lain, Day et al., 2015; Kelleher, 1999; Salm et al., 2000; Thomas \& Middleton, 2003). Dengan tetap mempertimbangkan secara seksama tantangan klasik, seperti keterbatasan sumberdaya manusia dan pendanaan, yang umum dihadapi oleh kawasan konservasi laut (cf. Gill et al, 2017), keberadaan RP berorientasi efektivitas pengelolaan merupakan persyaratan teknis minimum yang paling mungkin dipenuhi terlebih dahulu dalam jangka-pendek untuk 
memfasilitasi pengelolaan kawasan konservasi laut secara efektif (Day et al., 2015; Kelleher, 1999; Salm et al., 2000; Thomas \& Middleton, 2003). Tanpa RP berorientasi efektivitas, akan sulit bagi unit pengelola kawasan konservasi laut untuk membangun dan melaksanakan pengelolaan, apalagi meningkatkan kinerja dan efektivitas pengelolaan. Lebih jauh lagi, perkembangan mutakhir yang sangat menyarankan perlunya melakukan kajian evaluabilitas (evaluability assessment) untuk menilai kelayakan suatu program atau proyek untuk dievaluasi (Davies, 2013; Trevisan \& Walser, 2015) semakin memperkuat alasan mengapa kawasankawasan konservasi laut harus memiliki RP berorientasi efektivitas pengelolaan. Seperti yang diulas oleh Davies (2013), kelayakan evaluasi suatu program atau proyek atau kegiatan ditentukan oleh aspek-aspek seperti (i) desain intervensi program/proyek, (ii) ketersediaan data, dan (iii) konteks kelembagaan. Tiga aspek ini relevan dengan sebuah RP berorientasi efektivitas pengelolaan yang idealnya harus memiliki (i) desain intervensi yang dicantumkan dalam rencana pengelolaan, (ii) kerangka dan piranti pengumpulan data terkait dengan pengelolaan, dan (iii) badan pengelola dan kegiatan pengelolaan sebagai konteks yang menaunginya (Day et al., 2015; Kelleher, 1999; Salm et al., 2000; Thomas \& Middleton, 2003). Manakala tiga aspek tersebut belum terpenuhi, yang berarti evaluasi belum dapat dilakukan, hasil kajian evaluabilitas dapat digunakan untuk mengidentifikasi hal-hal yang perlu dilengkapi terlebih dahulu untuk memastikan evaluasi dapat dilaksanakan secara penuh kemudian (Longhurst et al., 2016; Trevisan \& Walser, 2015).

Untuk menyusun sebuah RP berorientasi efektivitas pengelolaan, perlu diketahui persyaratan-persyaratannya. Makalah ini memiliki dua tujuan. Pertama, makalah ini menyajikan hasil tinjauan terhadap persyaratan-persyaratan yang perlu dimiliki oleh sebuah RP agar ia berorientasi efektivitas pengelolaan. Kedua, menyajikan tata cara (prosedur) sederhana untuk meninjau seberapa jauh sebuah RP telah berorientasi efektivitas pengelolaan dan menyusun rekomendasi yang sesuai untuk mendorong pencapaiannya.

\section{Metodologi}

Penelitian dalam makalah ini menggunakan pendekatan kualitatif, dimana seluruh data dan informasi yang digunakan diperoleh melalui kajian terhadap dokumen-dokumen resmi publik, disamping mengacu kepada semua kepustakaan relevan yang tercantum pada Daftar Pustaka.

Untuk mengidentifikasi persyaratan-persyaratan bagi sebuah RP berorientasi efektivitas pengelolaan, penulis meninjau beberapa kepustakaan relevan, terutama buku Standar Terbuka untuk Praktik Konservasi (Open Standard for the Practice of Conservation atau OSPC) (Conservation Measures Partnership, 2020), dan publikasi dari Day et al. (2015), Kelleher (1999), Salm et al. (2000), dan Thomas \& Middleton (2003).

Untuk mengetahui isi rencana pengelolaan yang secara formal dikenal dengan sebutan Rencana Pengelolaan dan Zonasi (selanjutnya disingkat RPZ), penulis meninjau Peraturan Menteri Kelautan dan Perikanan Nomor 30 Tahun 2010 tentang Rencana Pengelolaan dan Zonasi Kawasan Konservasi Perairan (selanjutnya Permen KP 30/2010 tentang RPZ KKP) terutama pasal-pasal yang menyarankan isi sebuah dokumen RPZ. Disamping itu, penulis juga melakukan tinjauan cepat terhadap RPZ 10 kawasan konservasi perairan, pesisir dan pulau-pulau kecil yang berada di bawah yurisdiksi Kementerian 
Kelautan dan Perikanan (Tabel 1), untuk melihat pola penerapan Permen 30/2010 pada semua RPZ tersebut. Karena semua dokumen terbuka untuk dan dapat diakses oleh umum, pencarian dan pengumpulan Permen KP 30/2010 dan RPZ semua kawasan konservasi dilakukan dengan menggunakan bantuan fasilitas mesin pencari Google. Adapun kata kunci yang digunakan untuk pencarian dokumen adalah: peraturan menteri kelautan dan perikanan tentang rencana pengelolaan dan zonasi, dan rencana pengelolaan dan zonasi kawasan konservasi perairan nasional.

Selanjutnya, untuk meninjau orientasi efektivitas pengelolaan sebuah RP, persyaratan yang telah diidentifikasi diterapkan kepada RPZ dari salah satu kawasan konservasi perairan, pesisir dan pulau-pulau kecil, yaitu Taman Wisata Perairan (TWP) Gili Matra yang tertuang pada Surat Keputusan Menteri Kelautan dan Perikanan Nomor 57 Tahun 2014 tentang Rencana Pengelolaan dan Zonasi Taman Wisata Perairan Pulau Gili Ayer, Gili Meno dan Gili Trawangan di Provinsi Nusa Tenggara Barat Tahun 2014-2034 (selanjutnya disebut RPZ TWP Gili Matra).

Sebagai penutup, penulis menyarankan agar tata cara sederhana di atas dijadikan sebagai tata cara baku untuk meninjau seberapa jauh sebuah RPZ telah berorientasi efektivitas pengelolaan, dan menyusun rekomendasi yang sesuai untuk mendorong pencapaiannya secara penuh. Selain itu, penulis juga merekomendasikan rincian isi RPZ berorientasi efektivitas pengelolaan yang dapat digunakan untuk menyusun dokumen RPZ bagi kawasan-kawasan konservasi laut yang belum memilikinya.

Tabel 1. Daftar kawasan-kawasan konservasi perairan, pesisir dan pulau-pulau kecil yang berada di bawah yurisdiksi Kementerian Kelautan dan Perikanan

\begin{tabular}{|c|c|c|c|}
\hline No. & $\begin{array}{c}\text { Jenis dan Nama Kawasan } \\
\text { Konservasi }\end{array}$ & $\begin{array}{c}\text { Nomor dan Tahun Surat } \\
\text { Keputusan Menteri } \\
\text { Kelautan dan Perikanan }\end{array}$ & Pengelola \\
\hline 1 & $\begin{array}{l}\text { Taman Nasional Perairan } \\
\text { Laut Sawu (Provinsi Nusa } \\
\text { Tenggara Timur) }\end{array}$ & $06 / 2014$ & $\begin{array}{l}\text { Balai Kawasan Konservasi } \\
\text { Perairan Nasional (KKPN) } \\
\text { Kupang }\end{array}$ \\
\hline 2 & $\begin{array}{l}\text { Taman Wisata Perairan } \\
\text { (TWP) Pulau Pieh (Provinsi } \\
\text { Sumatera Barat) }\end{array}$ & $38 / 2014$ & Loka KKPN Pekanbaru \\
\hline 3 & $\begin{array}{l}\text { TWP Kepulauan Anambas } \\
\text { (Provinsi Kepulauan Riau) }\end{array}$ & $53 / 2014$ & Loka KKPN Pekanbaru \\
\hline 4 & $\begin{array}{l}\text { TWP Gili Matra (Provinsi } \\
\text { Nusa Tenggara Barat) }\end{array}$ & $57 / 2014$ & Balai KKPN Kupang \\
\hline 5 & $\begin{array}{l}\text { TWP Laut Banda (Provinsi } \\
\text { Maluku) }\end{array}$ & $58 / 2014$ & Balai KKPN Kupang \\
\hline 6 & $\begin{array}{l}\text { TWP Kepulauan Kapoposang } \\
\text { (Provinsi Sulawesi Selatan) }\end{array}$ & $59 / 2014$ & Balai KKPN Kupang \\
\hline 7 & $\begin{array}{l}\text { Suaka Alam Perairan (SAP) } \\
\text { Kepulauan Waigeo Sebelah } \\
\text { Barat (Provinsi Papua Barat) }\end{array}$ & $60 / 2014$ & Balai KKPN Kupang \\
\hline 8 & $\begin{array}{l}\text { TWP Kepulauan Padaido } \\
\text { (Provinsi Papua) }\end{array}$ & $62 / 2014$ & Balai KKPN Kupang \\
\hline 9 & $\begin{array}{l}\text { SAP Kepulauan Raja Ampat } \\
\text { (Provinsi Papua Barat) }\end{array}$ & $63 / 2014$ & Balai KKPN Kupang \\
\hline 10 & $\begin{array}{l}\text { SAP Kepulauan Aru } \\
\text { Tenggara (Provinsi Maluku) }\end{array}$ & $64 / 2014$ & Balai KKPN Kupang \\
\hline
\end{tabular}




\section{Hasil dan Pembahasan}

\subsection{Perencanaan Konservasi dengan Standar Terbuka}

Konservasi keanekaragaman dan sumberdaya hayati terbarukan memerlukan pendekatan yang komprehensif agar upaya-upaya yang dilakukan memberikan hasil dan dampak yang nyata (realized conservation outcomes and impacts) (Kapos et al., 2008, 2009). Untuk mendukung upaya komprehensif tersebut, para konservasionis bekerjasama mengembangkan pendekatan sistematis dan terstandarisasi yang dikenal dengan sebutan Open Standard for the Practice of Conservation (OSPC, atau Standar Terbuka untuk Praktik Konservasi) atau dikenal secara umum di dunia konservasi dengan sebutan Standar Terbuka (Conservation Measures Partnership, 2020). Standar yang diakui atau diadopsi oleh paling tidak 26 organisasi konservasi dan penyokong konservasi yang tersebar di seluruh dunia (Conservation Measures Partnership, 2020), terdiri dari lima langkah (Gambar 1) dan digunakan untuk mengelola kegiatan konservasi species atau ekosistem mulai dari tahap awal (persiapan) dan perencanaan, sampai tahap implementasi, evaluasi dan pembelajaran. Dalam penggunaannya, ia dibantu oleh sebuah piranti-lunak bernama Miradi (dapat diakses melalui tautan miradi.org) untuk membangun dan memvisualisasikan model diagramatik yang merepresentasikan semua hal yang terkait dengan upaya konservasi species atau ekosistem di sebuah tempat atau wilayah tertentu.

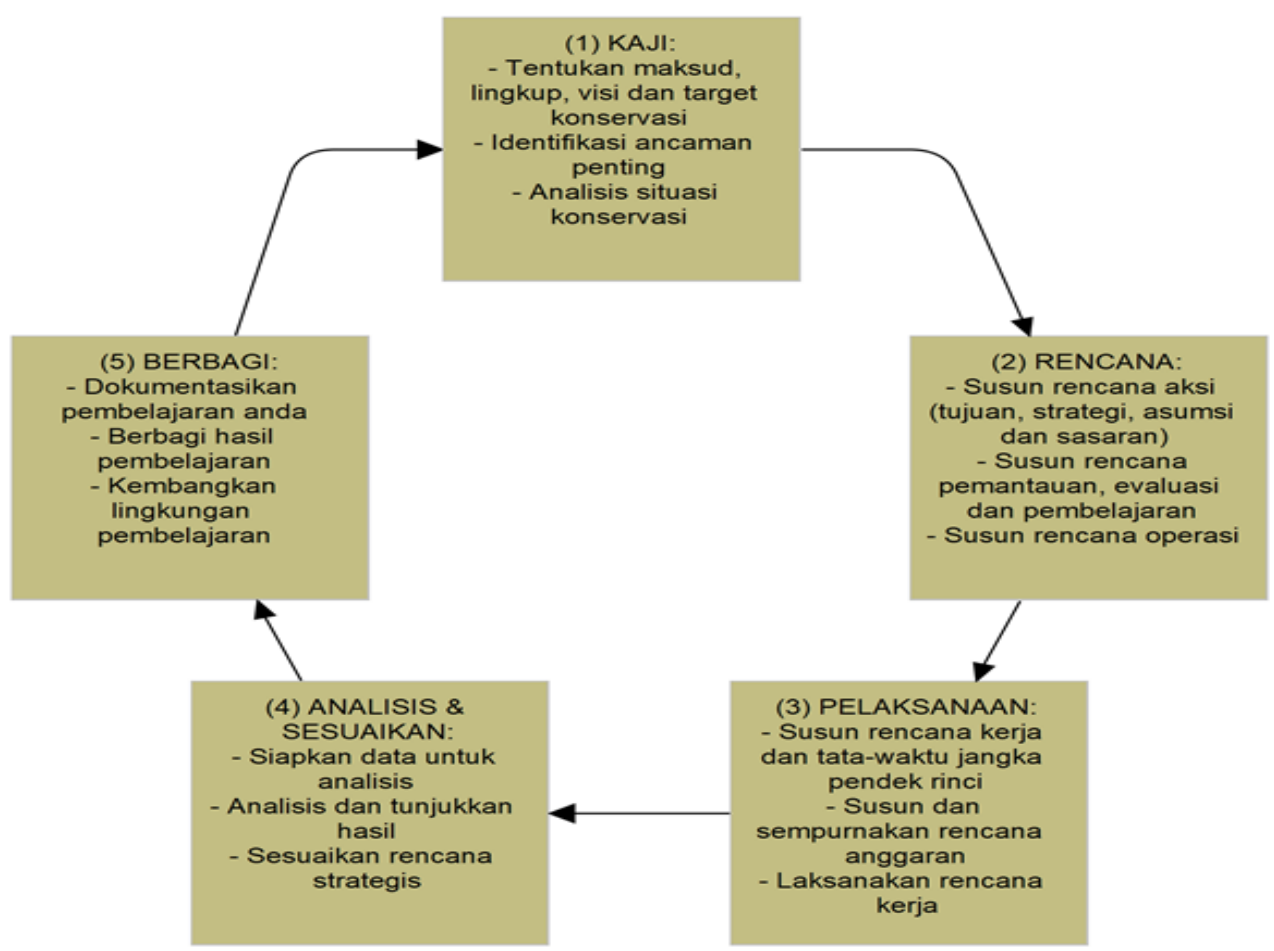

Gambar 1. Lima tahapan perencanaan konservasi dengan menggunakan Standar Terbuka untuk Praktik Konservasi 
Mengacu kepada Gambar 1, inti dari Standar Terbuka terletak pada dua tahapan pertama, yaitu (1) Kaji, dan (2) Rencana. Pada dua tahapan ini, semua kegiatan yang disarankan harus dilakukan dengan seksama, karena bila tidak semua tahapan selanjutnya tidak akan berjalan baik dan tidak dapat menjawab kebutuhan untuk meningkatkan kinerja dan efektivitas pengelolaan. Keluaran utama dari dua tahapan pertama ini adalah dua model diagramatik, yaitu (1) Model Konsep yang menggambarkan peta pikiran (mind map) dari penyusunnya (Gambar 2), sehingga ia dapat digunakan sebagai alat untuk melakukan analisis situasi, tentang problem yang dihadapi oleh upaya konservasi di suatu tempat atau wilayah; dan (2) Rantai Perubahan (results chains) yang mencerminkan teori perubahan (Theory of Change) (Gambar 3); disamping rencana monitoring dan rencana operasi terkait upaya pengelolaan.

Seperti yang dapat dilihat pada Gambar 2, Model Konsep dibangun oleh enam komponen standar. Komponen pertama adalah keanekaragaman dan sumberdaya hayati terbarukan sebagai inti dari upaya konservasi. Komponen kedua dan ketiga, ke arah kiri, adalah ancaman langsung maupun tak-langsung yang mengancam keberlanjutan keanekaragaman dan sumberdaya hayati terbarukan; dan komponen keempat adalah strategi yang dipilih untuk menangani ancaman-ancaman langsung dan tak-langsung. Selanjutnya, komponen kelima adalah jasa-jasa ekosistem dari keanekaragaman dan sumberdaya hayati terbarukan, yang dapat dinikmati oleh komponen keenam, yaitu manusia. Tanda panah yang keluar dari lingkaran komponen manusia merupakan umpan-balik logis dari upaya manusia dalam memanfaatkan dan mengelola sumberdaya hayati dalam konteks Sistem SosialEkologi atau Social-Ecological Systems (SESs) (Mascia et al., 2017).

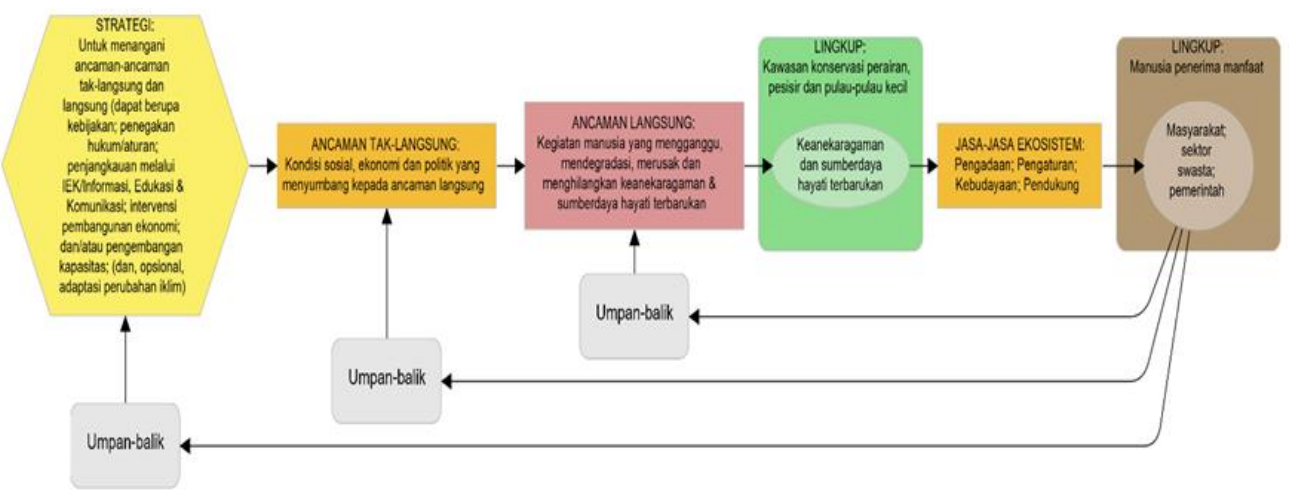

Gambar 2. Komponen standar Model Konsep untuk menunjukkan peta pikiran tentang persoalan konservasi species atau ekosistem di suatu tempat/wilayah.

Dalam sebuah Sistem Sosial-Ekologi, hubungan antara manusia dengan alam (atau ekosistem) merupakan hubungan sebab-akibat dalam lingkaran tertutup (closed loop) dimana setiap perubahan yang terjadi di alam sebagai akibat dari kegiatan manusia pada gilirannya akan memberi dampak atau umpan-balik, baik secara langsung maupun tak-langsung, terhadap manusia sendiri (Mascia et al., 2017). Cara pikir inilah yang melandasi prinsip dasar 
perencanaan konservasi, yaitu bukan keanekaragaman dan sumberdaya hayati yang dikelola, tetapi kegiatan manusia yang mengancam keberlanjutan keanekaragaman dan sumberdaya hayati yang harus dikelola (Conservation Measures Partnership, 2020) dengan menerapkan "perencanaan dan pengelolaan untuk mengurangi ancaman (yang berasal dari kegiatan manusia)" atau threat reductions management planning (Salafsky \& Margoluis, 1999; Margoluis \& Salafsky, 2001).

Diagram Model Konsep kemudian perlu disempurnakan dengan merinci setiap komponen (berdasarkan ketersediaan data dan informasi terbaik; best available data and information) agar bisa dilakukan analisis situasi untuk memahami lebih jauh dan rinci tentang problematika upaya konservasi yang dihadapi di suatu tempat/wilayah, dan mengidentifikasi cara (strategi) penanganan yang paling jitu (Conservation Measures Partnership, 2020).

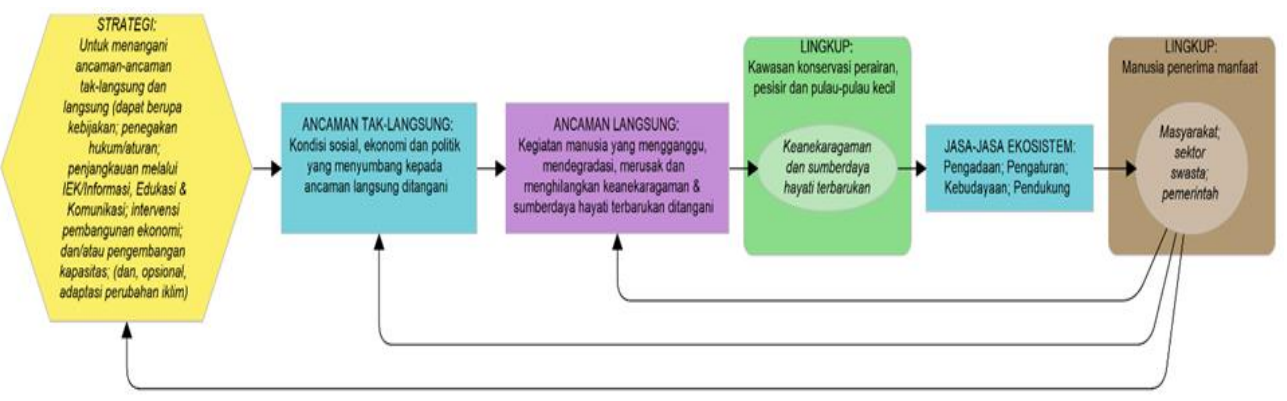

Gambar 3. Komponen standar Rantai Perubahan untuk menunjukkan Teori Perubahan akibat strategi intervensi yang diterapkan untuk konservasi species atau ekosistem di suatu tempat/wilayah.

Ditinjau dari sudut pandang pengelolaan konservasi, diperlukan Teori Perubahan yang dapat mencerminkan rangkaian perubahan-perubahan positif karena diterapkannya strategi yang telah dipilih, yang bermuara kepada terjaga atau meningkatnya kondisi keanekaragaman dan sumberdaya hayati. Teori Perubahan tersebut tercermin pada diagram yang ditampilkan pada Gambar 3, yang pada dasarnya adalah 'cermin positif dari diagram Model Konsep yang ditampilkan pada Gambar 2. Seperti yang dapat dilihat, semua pernyataan terkait dengan ancaman-ancaman langsung maupun tak-langsung kini bernada positif, mencerminkan keberhasilan dari pelaksanaan strategi-strategi yang sudah dipilih.

\subsubsection{Identifikasi Persyaratan bagi RP Berorientasi Efektivitas Pengelolaan}

Pada bagian awal makalah ini, disebutkan bahwa efektivitas pengelolaan didefinisikan sebagai "tingkat sejauh mana upaya pengelolaan mencapai tujuan dan sasaran (yang dinyatakan di dalam dokumen rencana pengelolaan)” (Hockings et al., 2000, 2006). Definisi ini selaras dan menguatkan saran bahwa sebuah RP sejak awal dan dalam proses penyusunannya bertumpu pada filosofi pengelolaan berbasis tujuan (management by objectives) (Thomas \& Middleton, 2003). Dengan demikian, penilaian efektivitas pengelolaan hanya dapat dilakukan bila tujuan dan sasaran pengelolaan yang relevan tercantum di dalam dokumen RP. Pertanyaannya kemudian, tujuan dan sasaran pengelolaan yang relevan seperti apakah yang harus dinyatakan pada sebuah dokumen RP? 
Sebelum menjawab pertanyaan tersebut, penulis mengajak sidang pembaca untuk melihat kembali tahapan perencanaan konservasi yang disajikan pada Gambar 1. Mengacu kepada gambar tersebut, tampak bahwa tujuan dan sasaran pengelolaan baru dapat disusun dan dinyatakan setelah masalah dan tantangan yang dihadapi oleh upaya konservasi telah diidentifikasi dan dirangkum dengan seksama (Conservation Measures Partnership, 2020). Sebelum tujuan dan sasaran dapat ditentukan, ada beberapa langkah pada tahap (1) Kaji yang harus diselesaikan terlebih dahulu. Langkah-langkah tersebut adalah sebagai berikut.

Pertama, kita perlu memilih dan menentukan target konservasi yaitu species atau ekosistem bagian dari keanekaragaman atau sumberdaya hayati terbarukan (di suatu tempat/wilayah) yang dinilai terancam oleh kegiatan-kegiatan manusia. Dalam Conservation Measures Partnership (2020: hal. 68), target konservasi didefinisikan sebagai "elemen keanekaragaman hayati (species, habitat, atau sistem ekologi) di sebuah tempat/wilayah yang dipilih sebagai fokus konservasi atau pengelolaan. Semua target seyogianya secara kolektif mewakili keanekaragaman hayati di suatu tempat/wilayah." (Sebagian ada yang menyebut target konservasi sebagai target keanekaragaman hayati, fokus konservasi, atau nilai konservasi). Maksud dari pemilihan target konservasi ini adalah untuk (i) digunakan sebagai acuan untuk mengidentifikasi ancaman-ancaman langsung dan tak-langsung yang dihadapi oleh target konservasi tersebut, sehingga (ii) intervensi atau strategi spesifik untuk menangani ancaman-ancaman tersebut dapat diidentifikasi dan dipilih. Lebih jauh lagi, target konservasi juga merupakan indikator keberhasilan (atau ketidakberhasilan) dari intervensi atau strategi yang dipilih selama kurun waktu tertentu.

Kedua, kita perlu mengidentifikasi kegiatan-kegiatan manusia yang mengancam langsung target konservasi. Mengacu kepada Gambar 2 dan 3, maka ancaman-ancaman langsung tersebut adalah semua kegiatan manusia yang "mengganggu, mendegradasi, merusak dan menghilangkan keanekaragaman dan sumberdaya hayati terbarukan.” Dalam Conservation Measures Partnership (2020: hal. 69), ancaman langsung didefinisikan sebagai "tindakan-tindakan terutama oleh manusia (antara lain, pembalakan liar atau penangkapan ikan secara tak berkelanjutan) yang dengan segera mendegradasi satu atau lebih target konservasi. Ancaman dapat juga berupa fenomena alam yang terganggu oleh kegiatan manusia (antara lain, meningkatnya peristiwa badai ekstrim akibat perubahan iklim). Ancaman biasanya terkait dengan satu atau lebih pemangku kepentingan.”

Ketiga, mengidentifikasi kegiatan-kegiatan manusia yang mengancam target konservasi secara tak-langsung. Mengacu kepada Gambar 2 dan 3, maka ancaman-ancaman tak-langsung tersebut adalah semua "kondisi atau keadaan sosial, ekonomi dan politik yang menyumbang kepada terjadinya ancaman-ancaman langsung." Dalam Conservation Measures Partnership (2020: hal. 69), ancaman tak-langsung didefinisikan sebagai "faktor-faktor yang diidentifikasi (oleh sebuah proyek) sebagai penyebab (terjadinya) ancaman langsung. Sebagai contoh, kebijakan penebangan hutan atau permintaan pasar terhadap ikan.” (kadang ia disebut juga dengan 'akar penyebab' atau 'penyebab pemicu').

Keempat, mengidentifikasi strategi atau cara-cara untuk menangani ancamanancaman langsung dan tak-langsung yang telah diidentifikasi di atas. Mengacu kepada Gambar 2 dan 3, maka strategi-strategi yang dapat dikembangkan secara umum dapat dikategorikan ke dalam enam kelompok, yaitu (1) kebijakan; (2) penegakan hukum/aturan; (3) penjangkauan (outreach) melalui penerapan metode Informasi, Edukasi dan Komunikasi 
(IEK); (4) intervensi pembangunan ekonomi; dan/atau (5) penguatan kapasitas (dan (6) tambahan sesuai kebutuhan: adaptasi terhadap perubahan iklim). Dalam Conservation Measures Partnership (2020: hal. 71), strategi didefinisikan sebagai "sekumpulan kegiatan yang memiliki fokus sama secara bersama-sama untuk mencapai tujuan dan sasaran tertentu dengan menyasar kepada titik-titik intervensi kunci, mengoptimalkan peluang-peluang, dan mengurangi kendala." (Sebuah strategi yang baik akan memenuhi kriteria seperti tertaut, fokus, layak, dan sesuai).

Selanjutnya, strategi pun harus dirinci menjadi sejumlah kegiatan yang berurutan secara logis untuk memastikan agar strategi tersebut dapat dicapai. Menurut Conservation Measures Partnership (2020, halaman 68), kegiatan adalah "sebuah tindakan spesifik atau sejumlah tugas/pekerjaan yang dilakukan oleh staf proyek dan/atau mitra untuk mencapai satu atau lebih sasaran." Kadang sebagian orang menyebut kegiatan dengan sebutan tindakan, tanggapan, atau tindakan strategis. Sebagai contoh, bila strategi yang dipilih adalah strategi kebijakan berupa penyusunan atau formulasi sebuah peraturan, maka tahapan kegiatan yang perlu dilalui adalah (i) identifikasi problem yang memerlukan peraturan untuk menanganinya dan membuat pernyataan masalah; (2) konsultasi dengan pemangku kepentingan untuk mempertajam analisis dan pernyataan masalah; (3) menyusun Kerangka Acuan Kerja bagi konsultan yang akan dipekerjakan; (4) menyewa konsultan dan menyusun naskah peraturan; dan seterusnya. Dengan menyusun semua kegiatan ini secara runtut maka pencapaian tujuan strategi dapat dilaksanakan.

Mengacu kepada pertanyaan "tujuan dan sasaran pengelolaan relevan seperti apakah yang harus dinyatakan pada sebuah dokumen RP” di atas, tampak jelas bahwa empat langkah yang sudah diulas di atas harus diselesaikan terlebih dahulu sebelum kita dapat membuat tujuan dan sasaran pengelolaan. Tujuan dan sasaran sendiri harus melekat pada strategi yang dipilih (dan kegiatan-kegiatan terkait) untuk menangani ancaman-ancaman langsung maupun tak-langsung. Tujuan dan sasaran yang dibuat harus memenuhi aturan SMART dengan rincian sebagai berikut (Conservation Measures Partnership, 2020: hal. 24):

- $\mathrm{S}=$ specific (tertentu) - tujuan/sasaran didefinisikan dengan jelas agar semua orang yang terlibat dalam proyek memiliki pemahaman sama terhadap istilah-istilah yang digunakan dalam tujuan/sasaran.

- $\mathrm{M}=$ measurable (dapat diukur) - tujuan/sasaran didefinisikan dalam skala pengukuran baku seperti angka, persentase, fraksi, atau pernyataan ada/tidak ada.

- $\mathrm{A}=$ achievable (dapat dicapai) - tujuan/sasaran dapat dicapai dan sesuai dengan konteks tapak proyek, dan kondisi politik, sosial dan finansial yang menaungi proyek.

- $\quad \mathrm{R}=$ results-oriented (berorientasi hasil) - tujuan/sasaran mencerminkan perubahanperubahan (positif) yang diperlukan dalam hal kondisi target konservasi, pengurangan ancaman, dan/atau hasil-hasil penting yang diharapkan lainnya.

- $\mathrm{T}=$ time-limited (dibatasi atau terikat waktu) - tujuan/sasaran seyogianya dapat dicapai dalam kurun waktu tertentu; umumnya dalam 1-10 tahun untuk sasaran (objective), dan 10-20 tahun untuk tujuan (goal).

Berikut adalah dua contoh tujuan dan sasaran menggunakan aturan SMART. 
Tujuan: “dampak positif pariwisata alam perairan (dalam kawasan konservasi laut) terhadap masyarakat setempat terwujud dalam kurun lima tahun sejak kegiatan wisata alam dikembangkan dalam kawasan, dimana kondisi terumbu karang sebagai atraksi wisata selam dan snorkeling selalu dijaga pada tutupan karang hidup $>65 \%$, dan jumlah wisatawan dan usahawan wisata selalu dijaga di bawah ambang-batas daya dukung sosial dan lingkungan kawasan, yaitu 200 wisatawan per minggu, dan 5 usaha per kawasan.”

Sasaran: "pada akhir 2025, stok ikan kerapu macan bernilai ekonomi tinggi kembali pada tingkat aman untuk ditangkap (spawning potential ratio atau SPR 0,30) dibandingkan dengan kondisi stok pada akhir 2022 (SPR 0,20).”

Pembaca yang tertarik untuk mendalami lebih jauh tentang tujuan dan sasaran SMART, serta bagaimana menyusunnya, penulis sarankan untuk mempelajari Adamcik et al. (2004).

Tabel 2. Persyaratan yang harus dimiliki oleh sebuah rencana pengelolaan (RP) berorientasi efektivitas pengelolaan, dan pertanyaan terkait untuk meninjau keberadaannya

\begin{tabular}{|c|c|c|}
\hline Nomor & Persyaratan & $\begin{array}{l}\text { Pertanyaan } \\
\end{array}$ \\
\hline 1 & Target konservasi & $\begin{array}{l}\text { Apakah RP telah memiliki daftar target konservasi yang } \\
\text { mencerminkan keanekaragaman atau sumberdaya hayati } \\
\text { terbarukan dalam kawasan konservasi laut yang dikelola? } \\
\text { Apakah jasa-jasa ekosistem target konservasi dan penerima } \\
\text { manfaatnya telah diidentifikasi? }\end{array}$ \\
\hline 2 & Ancaman langsung & $\begin{array}{l}\text { Apakah RP telah memiliki daftar ancaman langsung dari } \\
\text { kegiatan-kegiatan manusia yang mengganggu, mendegradasi, } \\
\text { merusak dan menghilangkan target konservasi dalam kawasan } \\
\text { konservasi laut yang dikelola, dan di perairan sekitarnya? } \\
\text { Apakah pemeringkatan dan prioritisasi ancaman langsung sudah } \\
\text { dilakukan berdasarkan tingkat keparahan, luasan dan } \\
\text { keterkembalian (reversibilitas) yang dialami oleh target } \\
\text { konservasi? }\end{array}$ \\
\hline 3 & Ancaman tak-langsung & $\begin{array}{l}\text { Apakah RP telah memiliki daftar ancaman tak-langsung berupa } \\
\text { kondisi atau keadaan sosial, ekonomi dan politik yang } \\
\text { menyumbang kepada terjadinya ancaman-ancaman langsung } \\
\text { terhadap target konservasi? }\end{array}$ \\
\hline 4 & Strategi dan kegiatan & $\begin{array}{l}\text { Apakah RP telah memiliki daftar strategi yang sesuai untuk } \\
\text { menangani satu atau beberapa ancaman-ancaman langsung dan } \\
\text { tak-langsung terhadap target konservasi sesuai dengan kriteria } \\
\text { Standar Terbuka (tertaut, fokus, layak, dan sesuai)? } \\
\text { Apakah setiap strategi telah dirinci menjadi satu atau lebih } \\
\text { rangkaian kegiatan yang berujung pada satu atau lebih ancaman } \\
\text { langsung dan tak-langsung? }\end{array}$ \\
\hline 5 & Tujuan dan sasaran & $\begin{array}{l}\text { Apakah setiap strategi telah memiliki tujuan (goal) yang } \\
\text { SMART? } \\
\text { Apakah rencana monitoring target konservasi untuk melihat } \\
\text { capaian (tujuan, keberhasilan) strategi yang telah dipilih sudah } \\
\text { ada? } \\
\text { Apakah setiap kegiatan sebagai bagian dari strategi telah } \\
\text { memiliki sasaran (objective) yang SMART? } \\
\text { Apakah rencana monitoring kegiatan untuk mencapai sasaran } \\
\text { yang telah ditentukan sudah ada? }\end{array}$ \\
\hline
\end{tabular}

Dari uraian di atas, dapat dirangkumkan bahwa persyaratan untuk menunjukkan sebuah RP telah berorientasi efektivitas pengelolaan adalah lima persyaratan yang disampaikan pada Tabel 2. Seperti yang dapat dilihat, setiap persyaratan didampingi dengan pertanyaan yang dapat digunakan untuk menguji kecenderungan sebuah RP terhadap efektivitas pengelolaan, atau untuk menyatakan bahwa sebuah RP telah berorientasi efektivitas pengelolaan. 
Selain lima persyaratan tersebut, sebetulnya masih ada satu persyaratan yang harus dipenuhi, yaitu tersedianya sistem pengambilan keputusan pengelolaan (management decision making system) (Day et al., 2015; Kelleher, 1999; Salm et al., 2000; Thomas \& Middleton, 2003). Pada kesempatan ini, persyaratan ini belum dimasukkan karena sistem pengelolaan kawasan-kawasan konservasi perairan, pesisir dan pulau-pulau kecil masih tersentralisasi di bawah yurisdiksi Kementerian Kelautan dan Perikanan, atau pemerintah daerah setempat.

\subsection{Rencana Pengelolaan dan Zonasi Kawasan Konservasi Perairan}

Rencana pengelolaan kawasan-kawasan konservasi perairan, pesisir dan pulau-pulau kecil, yang dikenal dengan sebutan Rencana Pengelolaan dan Zonasi (RPZ), penyusunannya dilakukan sesuai dengan arahan yang tercantum pada Permen KP 30/2010 tentang RPZ KKP. Seperti yang tercantum pada ayat (9) pasal 31 peraturan tersebut, daftar isi yang disarankan untuk sebuah RPZ dapat dilihat pada Tabel 3 berikut.

Tabel 3. Isi RPZ menurut ayat (9) pasal 31 Permen KP 30/2010

\begin{tabular}{|c|c|}
\hline Bab & Rincian isi \\
\hline Pendahuluan & $\begin{array}{ll}\text { - } & \text { Latar belakang; } \\
\text { - } & \text { Tujuan penyusunan rencana pengelolaan; dan } \\
\text { - } & \text { Ruang lingkup penyusunan rencana pengelolaan. }\end{array}$ \\
\hline $\begin{array}{l}\text { Potensi ekologis, ekonomi dan } \\
\text { sosial budaya kawasan serta } \\
\text { permasalahan pengelolaan }\end{array}$ & $\begin{array}{l}\text { - } \quad \text { Potensi ekologis; } \\
\text { - } \quad \text { Potensi ekonomi; } \\
\text { - } \quad \text { Potensi sosial-budaya; dan } \\
\text { - } \quad \text { Permasalahan pengelolaan. } \\
\end{array}$ \\
\hline Penataan Zonasi & $\begin{array}{l}\text { Sesuai dengan ayat (6) pasal } 31 \text { yang menerjemahkan } \\
\text { Bagian IV Zonasi Kawasan Konservasi Perairan. }\end{array}$ \\
\hline Kebijakan pengelolaan KKP & $\begin{array}{l}\text { - } \\
\text { Sesuai dengan pasal } 5 \text { ayat (2) yang meliputi (a) visi } \\
\text { dan misi; (b) tujuan dan sasaran pengelolaan; dan (c) } \\
\text { strategi pengelolaan. }\end{array}$ \\
\hline Strategi pengelolaan KKP & $\begin{array}{l}\text { - Sesuai dengan pasal } 6 \text { yang mencantumkan tiga } \\
\text { strategi pengelolaan, yaitu (1) penguatan } \\
\text { kelembagaan, (2) penguatan pengelolaan sumberdaya } \\
\text { kawasan, dan (3) penguatan sosial, ekonomi, dan } \\
\text { budaya. }\end{array}$ \\
\hline Program pengelolaan KKP & $\begin{array}{l}\text { - Sesuai dengan pilihan-pilihan program yang } \\
\text { tercantum pada ayat-ayat (2), (3) dan (4) pada pasal } 7 \\
\text { sebagai perluasan dari tiga strategi yang tercantum } \\
\text { pada pasal } 6 \text {. }\end{array}$ \\
\hline Rencana kerja pengelolaan KKP & 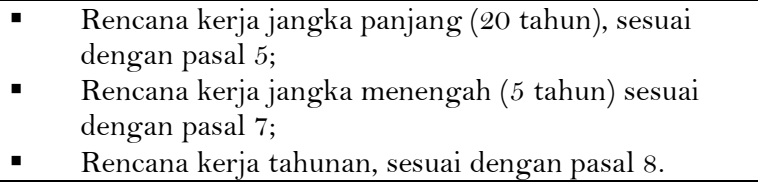 \\
\hline
\end{tabular}

Tinjauan terhadap RPZ 10 kawasan konservasi perairan nasional (KKPN) yang tersedia dan terbuka untuk umum, menunjukkan bahwa semuanya memiliki (daftar) isi yang serupa. Dimulai dengan bab Pendahuluan, bab-bab selanjutnya berbicara tentang (i) lingkup wilayah; (ii) lingkup materi yang mencakup potensi dan permasalahan pengelolaan, penataan zonasi, dan arahan rencana pengelolaan kawasan; dan (iii) lingkup jangka waktu yang meliputi rencana jangka panjang selama 20 (dua puluh) tahun, dan rencana jangka menengah selama 5 (lima) tahun. Kalaupun ada perbedaan dari daftar isi atau susunan yang ditampilkan 
pada Tabel 3, itu lebih disebabkan karena bab-bab kebijakan, strategi dan program pengelolaan digabungkan di bawah rencana kerja pengelolaan.

Dari tinjauan juga dijumpai beberapa hal yang perlu mendapat perhatian bagi penyusunan RPZ berorientasi efektivitas pengelolaan di masa mendatang. Pertama, perbedaan jenis kawasan konservasi tidak mempengaruhi RPZ yang dibuat, padahal paling tidak ada tiga jenis kawasan konservasi yang teridentifikasi (lihat Tabel 1), yaitu satu taman nasional perairan, enam taman wisata perairan, dan tiga suaka alam perairan. Mengacu kepada Panduan IUCN (Dudley, 2008), maka RPZ untuk masing-masing jenis kawasan berbeda karena suaka (atau cagar) masuk ke dalam kategori I, taman nasional kategori II, dan taman wisata kategori VI. Lebih jauh lagi, taman dan suaka memiliki perbedaan mendasar seperti kombinasi antara kegiatan pelindungan dan pemanfaatan berkelanjutan pada taman, dan kegiatan pelindungan saja pada suaka (Dudley, 2008Thomas \&; Middleton, 2003). Dengan demikian, setiap jenis kawasan harus memiliki RPZ yang khas, sesuai dengan jenis, tujuan dan fungsinya.

Kedua, tidak adanya pembedaan RPZ berdasarkan jenis kawasan tampaknya berimbas kepada penataan zonasi yang menjadi tidak spesifik. Semua kawasan konservasi laut memiliki zona-zona yang sama, yaitu (i) zona inti; (ii) zona perikanan berkelanjutan; (iii) zona pemanfaatan terbatas; dan (iv) zona lain (sesuai dengan Peraturan Pemerintah nomor 60 tahun 2006 tentang Konservasi Sumber Daya Ikan). Mengacu kepada kategori yang telah disinggung sebelumnya (Dudley, 2008), maka penataan zonasi seharusnya juga berbeda untuk setiap jenis kawasan. Untuk kawasan berbentuk suaka atau cagar yang fungsi utamanya adalah untuk melindungi keanekaragaman dan sumberdaya hayati terbarukan, hanya ada dua zona yang dapat didirikan, yaitu (1) zona inti, dan (2) zona lain berbentuk zona penyangga (buffer zone) untuk memisahkannya dari kegiatan eksploitasi yang terjadi di luar kawasan (Dudley, 2008). Demikian pula halnya dengan taman wisata laut yang fokusnya adalah wisata atau rekreasi, tentunya ia tidak memerlukan zona perikanan berkelanjutan di dalamnya, kecuali bila kawasan memang direncanakan untuk mendukung pariwisata berbasis perikanan (fisheries-based tourism) yang dikembangkan dengan tujuan mengurangi tekanan terhadap sumberdaya ikan dan mengalihkan mata-pencaharian ke sektor pariwisata (antara lain, Budzich-Tabor et al., 2014; Meneghello \& Mingotto, 2016; Muñoz, 2018; Piasecki et al., 2016). Hanya kawasan konservasi laut berbentuk taman nasional saja yang dapat memiliki semua zona dikarenakan ia digunakan untuk beragam pemanfaatan (multiple use) (Dudley, 2008).

Penataan zonasi yang telah dilakukan pada 10 kawasan konservasi perairan, pesisir dan pulau-pulau kecil di bawah yurisdiksi Kementerian Kelautan dan Perikanan menyarankan pendekatan yang digunakan belum komprehensif. Ini ditunjukkan oleh ketiadaan tujuan yang disematkan pada setiap zona dan indikator ekologi terkait yang diperlukan untuk menunjukkan efektivitas zona sebagai basis pengelolaan, dan tidak jelasnya hubungan antara zona-zona dengan strategi dan program pengelolaan spesifik yang dipilih untuk mengelola zona-zona tersebut. Padahal tekanan atau ancaman yang dihadapi oleh keanekaragaman dan sumberdaya hayati di setiap zona berbeda, sehingga diperlukan strategi pengelolaan yang berbeda pula untuk setiap zona. Ringkasnya, penataan zonasi menggunakan aturan yang terbatas kepada kegiatan-kegiatan yang boleh atau tidak boleh dilakukan, atau boleh dilakukan dengan ijin, tidak cukup kuat untuk menggambarkan 
kegunaan zonasi sebagai basis untuk mengelola kawasan. Seperti yang disarankan oleh Kelleher (1999), setiap zona yang didirikan dalam konteks pengelolaan kawasan konservasi hendaknya memiliki tujuan dan indikator ekologi/biologi yang relevan (Tabel 4), tujuannya tidak lain agar efektivitas zonasi sebagai basis pengelolaan dapat dievaluasi setelah satu kurun waktu tertentu (Day et al., 2015; Kelleher, 1999; Salm et al., 2000; Thomas \& Middleton, 2003).

Tabel 4. Contoh rincian tujuan dan indikator terkait untuk masing-masing zona yang mungkin didirikan dalam kawasan konservasi perairan, pesisir dan pulau-pulau kecil (sesuai ayat (1) pasal 9

Permen KP 30/2010 tentang RPZ KKP)

\begin{tabular}{|c|c|c|}
\hline Zona & Contoh Tujuan (SMART) & Indikator \\
\hline Inti & $\begin{array}{l}\text { "Menjaga atau meningkatkan species } \\
\text { (populasi) atau ekosistem dalam zona inti } \\
\text { selama } 5 \text { tahun ke depan dalam kisaran yang } \\
\text { dapat diterima mengacu kepada data garis- } \\
\text { dasar (baseline) termutakhir." }\end{array}$ & $\begin{array}{l}\text { Kondisi } \\
\text { habitat/ekosistem, species, } \\
\text { populasi ikan. } \\
\text { - Kualitas fisika-kimia- } \\
\text { geologi perairan. }\end{array}$ \\
\hline $\begin{array}{l}\text { Perikanan } \\
\text { Berkelanjutan }\end{array}$ & $\begin{array}{l}\text { "Menjaga atau meningkatkan stok species } \\
\text { ikan bernilai ekonomi dalam zona } \\
\text { perikanan berkelanjutan selama } 5 \text { tahun ke } \\
\text { depan dalam kisaran yang dapat diterima } \\
\text { mengacu kepada data garis-dasar (baseline) } \\
\text { perikanan tangkap termutakhir." } \\
\text { "Menjaga kualitas air dan sedimen di sub- } \\
\text { zona budidaya berkelanjutan selama } \\
\text { kegiatan budidaya dilaksanakan dengan } \\
\text { mengacu kepada data garis-dasar (baseline) } \\
\text { kualitas lingkungan budidaya } \\
\text { termutakhir." }\end{array}$ & $\begin{array}{l}\text { - Kondisi habitat dan } \\
\text { populasi ikan tangkap } \\
\text { (bernilai ekonomi, dan } \\
\text { bernilai atraksi wisata } \\
\text { mancing), atau budidaya. } \\
\text { - Kualitas fisika-kimia- } \\
\text { geologi perairan. }\end{array}$ \\
\hline $\begin{array}{l}\text { Pemanfaatan } \\
\text { Terbatas }\end{array}$ & $\begin{array}{l}\text { "Menjaga atau meningkatkan kondisi } \\
\text { sumberdaya hayati (misal, terumbu karang } \\
\text { atau mangrove) yang dijadikan atraksi wisata } \\
\text { dalam zona pemanfaatan terbatas selama } 5 \\
\text { tahun ke depan dalam kisaran yang dapat } \\
\text { diterima mengacu kepada data garis-dasar } \\
\text { (baseline) termutakhir." }\end{array}$ & $\begin{array}{l}\text { - Kondisi } \\
\text { habitat/ekosistem dan } \\
\text { sumberdaya hayati yang } \\
\text { dijadikan atraksi wisata } \\
\text { (terumbu karang, } \\
\text { mangrove). } \\
\text { - Kualitas fisika-kimia- } \\
\text { geologi perairan. }\end{array}$ \\
\hline Lain & $\begin{array}{l}\text { "Menjaga dan mendorong rehabilitasi atau } \\
\text { restorasi habitat/ekosistem agar tercapai } \\
\text { dalam kurun } 3 \text { tahun ke depan." }\end{array}$ & $\begin{array}{l}\text { Kondisi } \\
\text { habitat/ekosistem dan } \\
\text { sumberdaya hayati yang, } \\
\text { misalnya, direhabilitasi atau } \\
\text { direstorasi. } \\
\text { - Kualitas fisika-kimia- } \\
\text { geologi perairan. }\end{array}$ \\
\hline
\end{tabular}

Strategi pengelolaan yang tercantum pasal 6 dan program-program pengelolaan pada pasal 7 Permen KP 30/2010 tidak menunjukkan keselarasan dengan penataan zonasi yang telah dilakukan. Menurut hemat penulis, seharusnya semua strategi pengelolaan yang disajikan dalam dokumen RPZ dapat dibedakan antara strategi untuk kawasan secara keseluruhan, dan untuk masing-masing zona (Tabel 5). Strategi untuk keseluruhan kawasan, misalnya, meliputi peningkatan kepedulian dan dukungan masyarakat terhadap kawasan; sementara strategi untuk masing-masing zona, misalnya, untuk mengelola perikanan 
tangkap dan wisata mancing di zona perikanan berkelanjutan, atau untuk mengelola kegiatan wisata di zona pariwisata bahari berkelanjutan.

Pembedaan ini diperlukan karena kegiatan-kegiatan yang dapat dilakukan di setiap zona berbeda, dan setiap kegiatan memerlukan teknik monitoring yang juga berbeda dan spesifik (MMMPA Supervisory Board, 2016). Ini sesuai dengan tujuan (atau peruntukan) masing-masing zona yang disarankan oleh pasal 14-29 Permen KP 30/2010.

Tabel 5. Zona-zona dalam kawasan konservasi laut dan strategi yang sesuai

\begin{tabular}{|c|c|c|}
\hline Nama zona & $\begin{array}{c}\text { Strategi pengelolaan dan } \\
\text { kelengkapannya }\end{array}$ & Catatan \\
\hline Zona inti & $\begin{array}{l}\text { Strategi pengelolaan zona inti; } \\
\text { Tujuan dan sasaran pengelolaan } \\
\text { zona inti; } \\
\text { Target konservasi sebagai } \\
\text { indikator zona inti, dan rencana } \\
\text { monitoring target konservasi. }\end{array}$ & $\begin{array}{l}\text { Strategi meliputi (i) rencana } \\
\text { tindakan, termasuk rencana } \\
\text { monitoring, (ii) alokasi } \\
\text { sumberdaya, dan (iii) anggaran, } \\
\text { mengacu kepada tujuan dan } \\
\text { sasaran, target konservasi, dan } \\
\text { kegiatan-kegiatan yang boleh dan } \\
\text { tidak boleh dilakukan, atau dengan } \\
\text { ijin. }\end{array}$ \\
\hline $\begin{array}{l}\text { Zona perikanan } \\
\text { berkelanjutan }\end{array}$ & $\begin{array}{l}\text { Strategi pengelolaan zona } \\
\text { perikanan berkelanjutan; } \\
\text { Tujuan dan sasaran zona } \\
\text { perikanan berkelanjutan; } \\
\text { Target konservasi sebagai } \\
\text { indikator zona perikanan } \\
\text { berkelanjutan, dan rencana } \\
\text { monitoring target konservasi. }\end{array}$ & $\begin{array}{l}\text { Rincian strategi sama dengan di } \\
\text { atas, disesuaikan dengan kegiatan } \\
\text { yang akan dilakukan, misalnya, } \\
\text { perikanan tangkap, wisata } \\
\text { mancing, dan/atau budidaya } \\
\text { berkelanjutan. }\end{array}$ \\
\hline $\begin{array}{l}\text { Zona pemanfaatan } \\
\text { (misal, wisata bahari } \\
\text { berkelanjutan) }\end{array}$ & $\begin{array}{l}\text { Strategi pengelolaan zona wisata } \\
\text { bahari berkelanjutan; } \\
\text { Tujuan dan sasaran zona wisata } \\
\text { bahari berkelanjutan; } \\
\text { Target konservasi sebagai } \\
\text { indikator zona wisata bahari } \\
\text { berkelanjutan, dan rencana } \\
\text { monitoring target konservasi. }\end{array}$ & $\begin{array}{l}\text { Rincian strategi sama dengan di } \\
\text { atas, disesuaikan dengan kegiatan } \\
\text { yang akan dilakukan, misalnya, } \\
\text { berenang, snorkeling, menyelam, } \\
\text { dan/atau pengamatan satwa-liar } \\
\text { laut. }\end{array}$ \\
\hline $\begin{array}{l}\text { Zona lain (misal, } \\
\text { restorasi ekosistem) }\end{array}$ & $\begin{array}{l}\text { Strategi pengelolaan zona } \\
\text { restorasi ekosistem; } \\
\text { Tujuan dan sasaran zona restorasi } \\
\text { ekosistem; } \\
\text { Target konservasi sebagai } \\
\text { indikator zona restorasi } \\
\text { ekosistem, dan rencana } \\
\text { monitoring target konservasi. }\end{array}$ & $\begin{array}{l}\text { Rincian strategi sama dengan di } \\
\text { atas, disesuaikan dengan kegiatan } \\
\text { yang akan dilakukan, misalnya, } \\
\text { restorasi terumbu karang, } \\
\text { mangrove, padang lamun, } \\
\text { dan/atau populasi ikan tertentu. }\end{array}$ \\
\hline
\end{tabular}

\subsection{Meninjau Orientasi Efektivitas Pengelolaan}

Untuk menggambarkan orientasi efektivitas pengelolaan sebuah RP, semua pertanyaan pada Tabel 2 harus dijawab dengan lengkap. Semakin banyak pertanyaan yang dijawab, semakin tinggi kemungkinan RP tersebut untuk dinyatakan telah berorientasi efektivitas pengelolaan. Bila semua pertanyaan dijawab dengan baik dan lengkap, maka RP tersebut dinyatakan telah berorientasi efektivitas pengelolaan secara penuh. Seperti yang 
telah disinggung pada bab Metodologi, dalam makalah ini digunakan RPZ TWP Gili Matra sebagai dokumen yang ditinjau.

Sebelum menjawab semua pertanyaan, perlu dijelaskan terlebih dahulu bahwa penyusunan RP TWP Gili Matra dilakukan dengan pendekatan konvensional yang prosesnya berbeda dari pendekatan perencanaan konservasi menggunakan Standar Terbuka. Perbedaan cara ini kemudian berimbas kepada penggunaan istilah-istilah pada RP yang berbeda dari semua (istilah) persyaratan yang tercantum pada Tabel 2. Oleh karena itu, ketika meninjau RP, tidak dapat dilakukan perbandingan yang setara (apple to apple) dengan meninjau apakah istilah 'target konservasi' ada pada RP yang diperiksa, atau apakah istilah 'ancaman' tercantum pada RP, dan seterusnya. Sebelum menjawab setiap pertanyaan, peninjau wajib mempelajari dengan seksama isi RP untuk mencari kesesuaian istilah. Bila tidak, pemeriksaan tidak dapat dilanjutkan dan RP tidak dapat dinilai orientasi efektivitas pengelolaannya.

\section{Target Konservasi}

Apakah RP telah memiliki daftar target konservasi yang mencerminkan keanekaragaman atau sumberdaya hayati terbarukan dalam kawasan konservasi yang dikelola?

Pada RPZ TWP Gili Matra, aspek-aspek keanekaragaman atau sumberdaya hayati seperti species, habitat dan ekosistem, diuraikan pada sub-bab 'potensi ekologi' (halaman 613 berkas pdf; penomoran halaman mengikuti yang tercantum pada pdf reader karena halaman dokumen asli tidak berurutan dengan benar). Tinjauan menunjukkan TWP memiliki tiga ekosistem penting pesisir (terumbu karang, padang lamun, dan mangrove), komunitas/ padang kima (giant clams bed), species penyu yang dilindungi, dan dua tipe komunitas ikan (karang/demersal dan pelagis), yang semuanya dapat dinyatakan sebagai target konservasi.

Apakah jasa-jasa ekosistem target konservasi dan penerima manfaatnya telah diidentifikasi?

Jasa ekosistem dan penerima manfaatnya adalah hal baru bagi RP konvensional, sehingga dua hal ini tidak tercantum di dalam RPZ TWP Gili Matra. Meskipun demikian, Tabel 6 telah disiapkan untuk menyajikan sebuah daftar yang menunjukkan hubungan antara target konservasi, jasa ekosistem terkait, dan penerima manfaatnya.

Seperti yang dapat dilihat, setiap target konservasi memiliki atau memberikan beberapa jasa ekosistem sesuai dengan kategori yang disepakati pada Millennium Ecosystem Assessment atau MEA, yaitu (i) pendukung (supporting); (ii) pengaturan (regulating); (iii) budaya (cultural); dan (iv) pengadaan (provisioning) (UNEP, 2006). Sementara penerima manfaat dari jasa-jasa ekosistem tersebut beragam meliputi, antara lain, nelayan, wisatawan, masyarakat pesisir non-nelayan, pengusaha swasta (baik antara lain pariwisata/wisata dan perikanan), dan pemerintah setempat.

\section{Ancaman Langsung}

Apakah RP telah memiliki daftar ancaman langsung dari kegiatan-kegiatan manusia yang mengganggu, mendegradasi, merusak dan menghilangkan target konservasi dalam kawasan konservasi laut yang dikelola, dan di perairan sekitarnya?

Ancaman langsung adalah "semua kegiatan manusia yang mengganggu, mendegradasi, merusak dan menghilangkan keanekaragaman dan sumberdaya hayati 
terbarukan," atau "tindakan-tindakan terutama oleh manusia yang dengan segera mendegradasi satu atau lebih target konservasi” seperti yang dinyatakan oleh Conservation Measures Partnership (2020).

Pada RPZ TWP Gili Matra, tidak ada istilah ancaman yang dinyatakan secara eksplisit. Meskipun demikian, bila dirunut dengan seksama, maka kegiatan-kegiatan manusia yang berpotensi mengancam semua target konservasi diuraikan pada sub-bab 'potensi ekonomi' (halaman 13-23 berkas pdf). Berikut adalah beberapa kegiatan yang berpotensi mengancam langsung target konservasi yang telah diidentifikasi.

- Kegiatan penangkapan ikan terhadap populasi ikan karang/demersal dan pelagis (halaman 13-16 berkas pdf); dan

- Kegiatan wisata terutama selam-permukaan (snorkeling) dan menyelam (diving) terhadap ekosistem terumbu karang (halaman 16-23 berkas pdf).

Sementara kegiatan manusia yang berpotensi mengancam langsung kepada mangrove, padang lamun, penyu, dan kima, tidak tercantum atau dapat ditemukan dalam dokumen RPZ sehingga tidak dapat diidentifikasi untuk melengkapi daftar ancaman langsung. 
Tabel 6. Daftar target konservasi, jasa ekosistem dan penerima manfaat terkait

\begin{tabular}{|c|c|c|c|}
\hline Target konservasi & Jasa ekosistem & Penerima manfaat* & Kepustakaan \\
\hline $\begin{array}{l}\text { Ekosistem terumbu } \\
\text { karang }\end{array}$ & $\begin{array}{l}\text { Pendukung (supporting): habitat bagi biota } \\
\text { lain } \\
\text { Pengaturan (regulating): pelindungan pesisir, } \\
\text { penyangga kualitas air, dan siklus biogeokimia } \\
\text { Budaya (cultural): wisata selam \& snorkeling; } \\
\text { Pengadaan (provisioning): ikan konsumsi } \\
\text { bernilai ekonomi }\end{array}$ & $\begin{array}{l}\text { Langsung: nelayan, wisatawan, pengusaha } \\
\text { wisata/operator selam/tur; } \\
\text { Tak langsung: penduduk pesisir, pengusaha } \\
\text { pariwisata (hotel, rumah makan, transportasi), } \\
\text { pemerintah setempat. }\end{array}$ & $\begin{array}{l}\text { Woodhead et al. (2019), } \\
\text { UNEP (2006). }\end{array}$ \\
\hline Ekosistem mangrove & $\begin{array}{l}\text { Pendukung: habitat bagi biota lain } \\
\text { Pengaturan: pelindungan pesisir, penyangga } \\
\text { kualitas air, dan siklus biogeokimia } \\
\text { Budaya: wisata mangrove, wisata pengamatan } \\
\text { burung } \\
\text { Pengadaan: ikan dan non-ikan (a.l. kepiting) } \\
\text { konsumsi bernilai ekonomi }\end{array}$ & $\begin{array}{l}\text { Langsung: nelayan, wisatawan, pengusaha } \\
\text { wisata/operator tur; } \\
\text { Tak langsung: penduduk pesisir, pengusaha } \\
\text { pariwisata (hotel, rumah makan, transportasi), } \\
\text { pemerintah setempat. }\end{array}$ & $\begin{array}{l}\text { Bradley et al. (2008), Mitra } \\
\text { (2020), UNEP (2006). }\end{array}$ \\
\hline Ekosistem padang lamun & $\begin{array}{l}\text { Pendukung: habitat bagi biota lain } \\
\text { Pengaturan: penyangga kualitas air, penstabil } \\
\text { sedimen, dan siklus biogeokimia } \\
\text { Pengadaan: ikan konsumsi bernilai ekonomi }\end{array}$ & $\begin{array}{l}\text { Langsung: nelayan } \\
\text { Tak langsung: penduduk pesisir, pemerintah } \\
\text { setempat. }\end{array}$ & $\begin{array}{l}\text { Cullen-Unsworth \& } \\
\text { Unsworth (2013), UNEP } \\
\text { (2006). }\end{array}$ \\
\hline Komunitas/padang kima & $\begin{array}{l}\text { Pendukung: habitat dan penyedia makanan } \\
\text { bagi biota lain } \\
\text { Pengaturan: penyangga kualitas air } \\
\text { Budaya: atraksi wisata selam (?) }\end{array}$ & $\begin{array}{l}\text { Langsung: nelayan, wisatawan selam (?). } \\
\text { Tak langsung: penduduk pesisir, pemerintah } \\
\text { setempat. }\end{array}$ & Neo et al. (2015). \\
\hline $\begin{array}{l}\text { Species penyu yang } \\
\text { dilindungi }\end{array}$ & $\begin{array}{l}\text { Pendukung: perekayasa ekosistem (untuk } \\
\text { ekosistem lain seperti padang lamun, atau } \\
\text { untuk biota lain) } \\
\text { Pengaturan: perekayasa ekosistem }\end{array}$ & $\begin{array}{l}\text { Langsung: nelayan, wisatawan. } \\
\text { Tak langsung: penduduk pesisir, pemerintah } \\
\text { setempat. }\end{array}$ & Teelucksingh et al. (2010). \\
\hline
\end{tabular}




\begin{tabular}{|c|c|c|c|}
\hline & Budaya: atraksi wisata & & \\
\hline Ikan karang/demersal & $\begin{array}{l}\text { Pengadaan: ikan konsumsi bernilai ekonomi } \\
\text { Budaya: wisata mancing (?) }\end{array}$ & $\begin{array}{l}\text { Langsung: nelayan, pengusaha perikanan } \\
\text { tangkap; } \\
\text { Tak langsung: penduduk pesisir dan non- } \\
\text { pesisir, pengusaha transportasi, pemerintah } \\
\text { setempat. }\end{array}$ & $\begin{array}{l}\text { Holmlund \& Hammer } \\
\text { (1999), Piet et al. (2017). }\end{array}$ \\
\hline Ikan pelagis & $\begin{array}{l}\text { Pengadaan: ikan konsumsi bernilai ekonomi } \\
\text { Budaya: wisata mancing (?) }\end{array}$ & $\begin{array}{l}\text { Langsung: nelayan, pengusaha perikanan } \\
\text { tangkap; } \\
\text { Tak langsung: penduduk pesisir dan non- } \\
\text { pesisir, pengusaha transportasi, pemerintah } \\
\text { setempat. }\end{array}$ & $\begin{array}{l}\text { Holmlund \& Hammer } \\
\text { (1999), Piet et al. (2017). }\end{array}$ \\
\hline
\end{tabular}

Keterangan: *Identifikasi penerima manfaat dilakukan secara sepihak oleh penulis berdasarkan data dan informasi terbatas yang tersedia. 
Untuk melengkapi ancaman-ancaman langsung terhadap mangrove, padang lamun, penyu, dan kima (serta melengkapi ancaman langsung lain terhadap terumbu karang dan populasi-populasi ikan karang/demersal dan pelagis bernilai ekonomis), penulis menyusun Tabel 7 yang menyajikan daftar ancaman-ancaman langsung yang dapat digunakan untuk meninjau ancaman-ancaman langsung akibat kegiatan manusia di suatu tempat atau wilayah dimana sebuah kawasan konservasi berada.

Tabel 7. Daftar ancaman-ancaman langsung terhadap target konservasi berbeda berdasarkan kajian kepustakaan

\begin{tabular}{|c|c|c|}
\hline Target Konservasi & Ancaman Langsung & Kepustakaan \\
\hline $\begin{array}{l}\text { Ekosistem terumbu } \\
\text { karang }\end{array}$ & 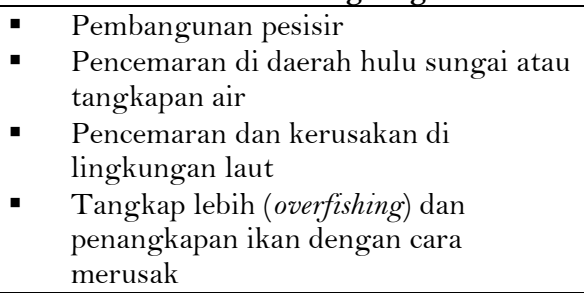 & Burke et al. (2011). \\
\hline Ekosistem mangrove & 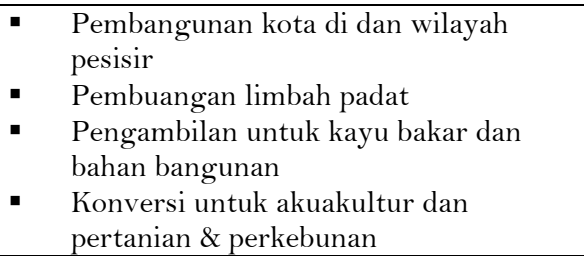 & Webber et al. (2016). \\
\hline Ekosistem padang lamun & $\begin{array}{ll}\text { - } & \text { Pembangunan pesisir } \\
\text { - } & \text { Kualitas air yang buruk } \\
\text { - } & \text { Kerusakan mekanis } \\
\text { - } & \text { Budidaya } \\
\text { - } & \text { Penangkapan ikan } \\
\text { - } & \text { Sedimentasi }\end{array}$ & Short et al. (2011). \\
\hline Komunitas/padang kima & 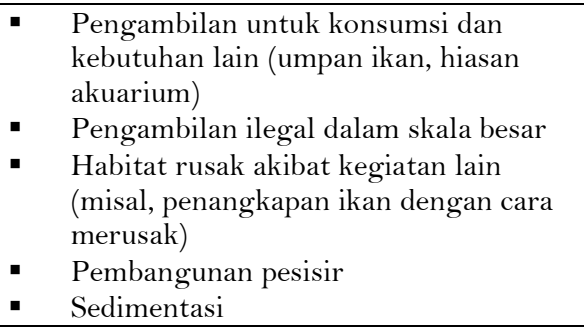 & Neo et al. (2017). \\
\hline $\begin{array}{l}\text { Species penyu yang } \\
\text { dilindungi }\end{array}$ & 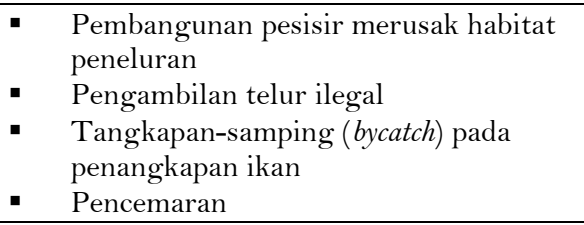 & Hamann et al. (2010). \\
\hline $\begin{array}{l}\text { Ikan karang/demersal } \\
\text { dan pelagis }\end{array}$ & $\begin{array}{ll}\text { - } & \text { Tangkap lebih (overfishing) } \\
\text { - } & \text { Penangkapan ikan dengan cara } \\
\text { merusak (destructive fishing) } \\
\text { - } & \text { Kerusakan habitat } \\
\text { - } & \text { Pencemaran } \\
\end{array}$ & $\begin{array}{l}\text { Arthington et al } \\
(2016) \text {. }\end{array}$ \\
\hline
\end{tabular}


Ditinjau dari sisi perencanaan konservasi, melakukan identifikasi ancaman langsung relatif mudah karena telah baku dari segi definisi dan indikator dan kriteria pengukurannya (luasan, keparahan dan keterkembalian) (Conservation Measures Partnership, 2020). Tetapi, dari sisi masyarakat, pengalaman menunjukkan bahwa tidak mudah untuk mengidentifikasi ancaman langsung secara partisipatif bersama mereka. Disamping akibat terbatasnya pengetahuan dan informasi yang dimiliki oleh masyarakat; umumnya masyarakat setempat enggan untuk mengakui keberadaan ancaman yang berasal dari kegiatan mereka sendiri dan lebih sering menyalahkan orang lain dari luar atau desa lain sebagai pelaku kegiatan yang mengancam. Untuk mengantisipasi hal ini, maka ada 3 cara untuk mengidentifikasi ancaman: menanyakan dan mencatat (1) kegiatan yang secara jelas merusak keanekaragaman dan sumberdaya hayati seperti, misalnya, penggunaan bom dan racun untuk menangkap ikan; (2) kondisi, misalnya, kegiatan penangkapan saat survei dilakukan, apakah ukuran ikan yang ditangkap tetap sama atau semakin kecil dibandingkan di masa lampau, atau semakin jauh dan semakin lama waktu untuk mendapatkan ikan; dan (3) keberadaan konflik antara sesama anggota masyarakat yang bekerja di sektor berbeda, misal nelayan versus pekerja atau kegiatan pariwisata.

Apakah pemeringkatan dan prioritisasi ancaman langsung sudah dilakukan berdasarkan tingkat keparahan, luasan dan keterkembalian (reversibilitas) yang dialami oleh target konservasi?

Keterbatasan data dan informasi pada RP menghalangi upaya untuk menyusun prioritisasi target konservasi. Untuk sementara, diasumsikan bahwa semua target konservasi yang telah diidentifikasi menghadapi tekanan yang relatif serupa dari beragam kegiatan yang dilakukan di dalam atau di sekitar kawasan TWP, seperti pariwisata bahari dan perikanan tangkap.

\section{Ancaman Tak Langsung}

Apakah RP telah memiliki daftar ancaman tak-langsung berupa kondisi atau keadaan sosial, ekonomi dan politik yang menyumbang kepada terjadinya ancaman-ancaman langsung terhadap target konservasi?

Tinjauan menunjukkan bahwa sedikit sekali ancaman-ancaman tak-langsung yang dapat diidentifikasi dari RPZ TWP Gili Matra. Beberapa yang dapat diidentifikasi tercantum pada sub-bab 'potensi sosial-budaya' (halaman 23-35 berkas pdf), yaitu hasil penelitian tentang persepsi dan dukungan masyarakat terhadap kawasan (halaman 26-29 berkas pdf); dan pada sub-bab 'permasalahan pengelolaan' yang meliputi (i) konflik sosial, (ii) pergeseran nilai budaya, dan (iii) lemahnya penegakan hukum (halaman 34-35 berkas pdf).

Pada sub-bab 'permasalahan pengelolaan' disampaikan beberapa hal yang sebetulnya adalah indikator akibat (indicators of effects) dari kegiatan-kegiatan manusia yang dilakukan di dalam kawasan TWP Gili Matra, yaitu (i) degradasi terumbu karang; (ii) perubahan garis pantai; (iii) pencemaran; dan (iv) ketersediaan air tawar (halaman 32-34 berkas pdf). Menurut hemat penulis, semua hal yang disampaikan pada sub-bab 'permasalahan pengelolaan' sebetulnya bukan permasalahan pengelolaan karena mereka bukan akar penyebab masalah. Mereka adalah manifestasi dari kegiatan-kegiatan utama yang terjadi di TWP Gili Matra, yaitu perikanan tangkap dan pariwisata bahari. Penyebab dari persoalan yang dihadapi oleh TWP sebetulnya sudah tercantum pada sub-bab 'permasalahan pengelolaan' hanya tampaknya penyusun RPZ mengalami kesulitan dalam membingkai (framing) hubungan 
sebab-akibat untuk mengidentifikasi akar penyebab masalah yang harus ditangani kemudian melalui pengelolaan. Hal ini dapat dilihat pada degradasi terumbu karang (yang antara lain disebabkan oleh penangkapan ikan menggunakan cara muro-ami, dan pembuangan jangkar yang tidak terkendali), dan pencemaran (yang disebabkan oleh ketiadaan sarana-prasarana pengelolaan limbah).

Untuk membantu menggambarkan hubungan sebab-akibat antara ancaman-ancaman tak-langsung dengan ancaman-ancaman langsung yang dihadapi oleh target konservasi, penulis menyusun Tabel 8. Tabel tersebut menyajikan daftar ancaman tak-langsung yang menyumbang, baik secara linier dan/atau non-linier, kepada kegiatan manusia yang menimbulkan ancaman langsung terhadap target konservasi di suatu tempat atau wilayah dimana sebuah kawasan konservasi berada. Perlu ditekankan disini bahwa bukan tidak mungkin di antara ancaman-ancaman tak-langsung juga terjadi hubungan sebab-akibat. Sebagai contoh, terbatasnya masyarakat setempat yang terlibat (dalam kegiatan pengelolaan kawasan) menyebabkan rendahnya kepatuhan masyarakat terhadap peraturan kawasan; dua hal ini adalah ancaman-ancaman tak-langsung. Selain itu, bukan tidak mungkin satu ancaman tak-langsung menyumbang kepada ancaman langsung terhadap lebih dari satu target konservasi. Sebagai contoh, lemahnya penegakan hukum/aturan terkait dengan pengelolaan perikanan menyebabkan terjadinya penangkapan ikan dengan cara merusak yang tidak saja mengancam ikan karang/demersal sendiri tetapi juga ekosistem terumbu karang.

\section{Strategi dan Kegiatan}

Apakah RP telah memiliki daftar strategi yang sesuai untuk menangani satu atau beberapa ancaman-ancaman langsung dan tak-langsung terhadap target konservasi sesuai dengan kriteria Standar Terbuka (tertaut, fokus, layak, dan sesuai)?

Tinjauan menunjukkan bahwa semua strategi yang dicantumkan pada RPZ TWP Gili Matra tidak mencerminkan hal-hal yang disarankan pada definisi strategi yang disarankan oleh Conservation Measures Partnership (2020), yaitu "sekumpulan kegiatan yang memiliki fokus sama secara bersama-sama untuk mencapai tujuan dan sasaran tertentu dengan menyasar kepada titik-titik intervensi kunci, mengoptimalkan peluang-peluang, dan mengurangi kendala." Umumnya strategi terlalu terpaku kepada yang disarankan oleh pasal 6 Permen KP 30/2010, yaitu strategi untuk memperkuat aspek (i) kelembagaan, (ii) pengelolaan sumber daya kawasan, dan (iii) sosial, ekonomi dan budaya (halaman 84-85 berkas pdf). Tiga strategi ini relatif berbeda dari enam pilihan strategi yang ditawarkan oleh Conservation Measures Partnership (2020), yaitu (1) kebijakan, (2) penegakan hukum/aturan, (3) penjangkauan dengan menerapkan metode Informasi, Edukasi dan Komunikasi (IEK); (4) intervensi pembangunan ekonomi; dan/atau (5) penguatan kapasitas.

Karena dokumen RPZ memang tidak mencantumkan persyaratan yang menunjukkan ia telah berorientasi efektivitas pengelolaan, maka dapat dipastikan tidak dapat ditemukan strategi-strategi yang sesuai untuk menangani ancaman-ancaman langsung dan taklangsung. Dengan demikian, dapat dikatakan bahwa RPZ TWP Gili Matra tidak memiliki strategi yang mendukung upaya pengelolaan yang efektif. Hal ini juga memperkuat anggapan bahwa RPZ yang telah disusun tidak fokus karena tidak jelas tentang hal apa yang akan ditangani dan dikelola. Menurut hemat penulis, sebaiknya strategi penguatan 
kelembagaan tidak dinyatakan dalam sebuah dokumen RP karena ia menyebabkan dokumen tidak fokus kepada pengelolaan. Ia sebaiknya menjadi sebuah dokumen terpisah yang berjudul, misalnya, strategi penguatan kelembagaan pengelola kawasan konservasi laut (di sebuah tempat), sebagai dokumen tambahan bagi RP.

Apakah setiap strategi telah dirinci menjadi satu atau lebih rangkaian kegiatan yang berujung pada satu atau lebih ancaman langsung dan tak-langsung?

Tinjuan menunjukkan bahwa umumnya kegiatan yang direncanakan terlalu terpaku kepada program-program yang disarankan oleh pasal 7 Permen KP 30/2010 (halaman 85187 berkas pdf), dan tidak mencerminkan definisi kegiatan menurut Conservation Measures Partnership (2020), yaitu "sebuah tindakan spesifik atau sejumlah tugas/pekerjaan yang dilakukan oleh staf proyek dan/atau mitra untuk mencapai satu atau lebih sasaran.” Semua program tersebut bersifat dini dan antisipatif (pre-emptive), sehingga meski tampak menjanjikan pada kenyataannya mereka telah membelenggu para penyusun dokumen untuk berkreasi menemukan program dan kegiatan yang paling cocok untuk menangani persoalan atau tantangan yang (akan) dihadapi di lapangan. Disamping itu, sebagian program di bawah strategi penguatan kelembagaan bukan untuk mengelola kawasan secara langsung, tetapi untuk mendukung agar pengelolaan kawasan efektif, khususnya yang berada di bawah strategi penguatan kelembagaan.

Tabel 8. Daftar beberapa pilihan ancaman tak-langsung terhadap target konservasi berbeda berdasarkan kajian pustaka

\begin{tabular}{|c|c|c|c|}
\hline Ancaman Tak-Langsung* & Ancaman Langsung & $\begin{array}{c}\text { Target } \\
\text { Konservasi }\end{array}$ & Kepustakaan \\
\hline $\begin{array}{l}\text { Kebijakan atau peraturan tidak } \\
\text { tersedia } \\
\text { Kebijakan atau peraturan tidak } \\
\text { berorientasi kepada } \\
\text { keberlanjutan } \\
\text { Peraturan tersedia tetapi } \\
\text { pelanggaran tetap terjadi }\end{array}$ & $\begin{array}{ll}\text { - } & \text { Pembangunan pesisir } \\
\text { - } & \text { Pencemaran di daerah hulu } \\
\text { sungai atau tangkapan air } \\
\text { - } \quad \text { Pencemaran dan kerusakan di } \\
\text { lingkungan laut } \\
\text { - Tangkap lebih (overfishing) } \\
\text { dan penangkapan ikan } \\
\text { dengan cara merusak }\end{array}$ & $\begin{array}{l}\text { Ekosistem } \\
\text { terumbu karang }\end{array}$ & $\begin{array}{l}\text { Burke et al. } \\
\text { (2010), Lachs } \\
\text { \& Onate- } \\
\text { Casado } \\
\text { (2020), } \\
\text { Wilkinson } \\
\text { (2008). }\end{array}$ \\
\hline $\begin{array}{l}\text { hukum/aturan yang lemah } \\
\text { Peraturan tersedia tetapi } \\
\text { pelanggaran tetap terjadi } \\
\text { karena rendahnya kepedulian } \\
\text { dan kepatuhan para pelaku } \\
\text { kegiatan dan masyarakat }\end{array}$ & 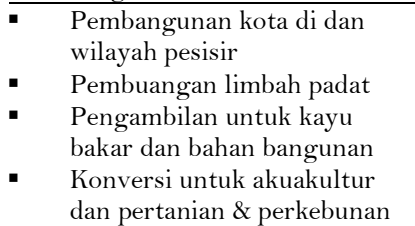 & $\begin{array}{l}\text { Ekosistem } \\
\text { mangrove }\end{array}$ & $\begin{array}{l}\text { Bradley et al. } \\
\text { (2008), } \\
\text { Weber et al. } \\
(2016) .\end{array}$ \\
\hline $\begin{array}{l}\text { mendorong tingginya } \\
\text { pengambilan (eksploitasi) } \\
\text { sumberdaya untuk memenuhi } \\
\text { pasok } \\
\text { Kapasitas untuk } \\
\text { mengendalikan dan mengelola }\end{array}$ & $\begin{array}{ll}\text { - } & \text { Pembangunan pesisir } \\
\text { - } & \text { Kualitas air yang buruk } \\
\text { - } & \text { Kerusakan mekanis } \\
\text { - } & \text { Budidaya } \\
\text { - } & \text { Penangkapan ikan } \\
\text { - } & \text { Sedimentasi }\end{array}$ & $\begin{array}{l}\text { Ekosistem padang } \\
\text { lamun }\end{array}$ & $\begin{array}{l}\text { Short et al. } \\
\text { (2011), } \\
\text { Unsworth et } \\
\text { al. (2019). }\end{array}$ \\
\hline $\begin{array}{l}\text { kegiatan yang mengancam } \\
\text { langsung lemah } \\
\text { Kapasitas untuk menangani } \\
\text { kegiatan yang mengancam } \\
\text { tak-langsung lemah } \\
\text { Kapasitas untuk melakukan } \\
\text { restorasi dan rehabilitasi } \\
\text { lemah } \\
\text { Pelibatan masyarakat setempat } \\
\text { terbatas }\end{array}$ & $\begin{array}{ll}\text { Pengambilan untuk konsumsi } \\
\text { dan kebutuhan lain (umpan } \\
\text { ikan, hiasan akuarium) } \\
\text { Pengambilan ilegal dalam } \\
\text { skala besar } \\
\text { Habitat rusak akibat kegiatan } \\
\text { lain (misal, penangkapan ikan } \\
\text { dengan cara merusak) } \\
\text { - Pembangunan pesisir } \\
\text { - Sedimentasi }\end{array}$ & $\begin{array}{l}\text { Komunitas/padang } \\
\text { kima }\end{array}$ & $\begin{array}{l}\text { Neo et al. } \\
(2015,2017)\end{array}$ \\
\hline
\end{tabular}




Tidak ada insentif untuk
mendorong dukungan lebih
luas
Terbatasnya sarana dan
prasarana pengelolaan limbah
Terbatasnya sarana dan
prasarana pengelolaan
kawasan
Keterangan:
*Ancaman tak-langsung ini
adalah daftar terpilih yang dapat
diidentifikasi melalui survei
pustaka; oleh karena itu jenis dan
jumlahnya dapat bertambah
sesuai dengan data dan informasi
baru.

Seperti yang telah disinggung pada sub-bab sebelumnya, sebaiknya semua program di bawah strategi penguatan kelembagaan tidak menjadi bagian dari sebuah dokumen RP karena ia menyebabkan dokumen tidak fokus kepada pengelolaan. Sangat disarankan agar dokumen RP hanya menyajikan strategi dan kegiatan yang terkait langsung dengan pengelolaan aspek-aspek keanekaragaman dan sumberdaya hayati, dan sosial-ekonomibudaya masyarakat saja.

\section{Tujuan dan Sasaran}

\section{Apakah setiap strategi telah memiliki tujuan (goal) yang SMART?}

Seperti yang sudah disinggung di bagian awal bab Pendahuluan, efektivitas pengelolaan didefinisikan sebagai "tingkat sejauh mana upaya pengelolaan mencapai tujuan dan sasaran (yang dinyatakan di dalam dokumen rencana pengelolaan)” (Hockings et al., 2000, 2006). Dengan demikian, dapat dikatakan bahwa untuk melakukan evaluasi efektivitas pengelolaan harus ada tujuan dan sasaran pengelolaan yang dapat dijadikan acuan dalam melaksanakan evaluasi. Dalam konteks pengelolaan kawasan, tujuan dan sasaran tersebut melekat pada strategi-strategi dan semua kegiatan atau tindakan pengelolaan yang terkait dengan mereka (Conservation Measures Partnership, 2020; Thomas \& Middleton, 2003). Perlunya ada tujuan dan sasaran yang masing-masing disematkan kepada strategi dan kegiatan terkait karena efektivitas pengelolaan merupakan manifestasi dari kinerja pengelolaan yang dipengaruhi oleh beberapa faktor seperti rencana kerja atau tindakan yang cocok, alokasi sumberdaya dan anggaran (Alogan \& Yetis, 2006; Thomas \& Middleton, 2003; Uraidi \& Kumar, 2016). Aspek-aspek ini kemudian dapat digunakan untuk merunut dukungan terhadap pengelolaan dan menyusun rekomendasi yang sesuai sekiranya ada kesenjangan antara kegiatan yang dilakukan dengan dukungan yang diharapkan (Alogan \& Yetis, 2006; Thomas \& Middleton, 2003; Uraidi \& Kumar, 2016).

Tinjauan terhadap semua strategi yang dicantumkan di dalam RPZ TWP Gili Matra, menunjukkan bahwa sebagian besar strategi, baik pengelolaan jangka panjang (halaman 81 86 berkas pdf) maupun pengelolaan jangka menengah 5 tahun (halaman 90-188 berkas pdf), belum mencantumkan tujuan yang SMART. Pada halaman 82-83 berkas pdf dicantumkan sebuah daftar tujuan yang 'cukup' SMART tetapi tujuan-tujuan tersebut tidak mencantumkan strategi yang memayunginya. Tidak adanya tujuan yang SMART dicantumkan dalam RPZ memperkuat anggapan bahwa RPZ tidak memiliki fokus pengelolaan yang jelas. 
Apakah rencana monitoring target konservasi untuk melihat capaian (tujuan, keberhasilan) strategi yang telah dipilih sudah ada?

Monitoring, penulis definisikan sebagai "pengumpulan dan analisis data secara periodik untuk merunut (atau melacak kemajuan) apakah pelaksanaan strategi dan kegiatan sedang menuju kepada pencapaian tujuan dan sasaran terkait" (cf. Conservation Measures Partnership, 2020, halaman 70). Melalui monitoring secara sistematis, unit pengelola dapat melacak perubahan biologi/ekologi yang disebabkan oleh manusia di alam (Hiscock, 1998). Oleh karenanya, ia perlu didampingi dengan sebuah rencana monitoring yang dirancang secara seksama dan umumnya berisi informasi yang dibutuhkan, indikator, metode yang digunakan, tata waktu, dan siapa yang bertanggungjawab melakukan pengumpulan data (Conservation Measures Partnership, 2020; MMMPA Supervisory Board, 2016). Perkembangan mutakhir yang menyarankan agar monitoring, evaluasi dan pelaporan dipadukan untuk mendukung proses pengambilan keputusan pengelolaan (management decision making) (Addison et al., 2018) semakin memperkuat keterkaitan antara monitoring dan evaluasi.

Tinjauan terhadap RPZ TWP Gili Matra tidak menemukan sama sekali sebuah rencana monitoring terhadap target konservasi atau indikator yang disematkan kepada setiap strategi. Hal ini menyarankan bahwa dokumen tersebut tidak operasional atau tidak dapat langsung diterapkan. SMART?

Apakah setiap kegiatan sebagai bagian dari strategi telah memiliki sasaran (objective) yang

Tinjauan terhadap semua kegiatan yang yang dicantumkan dalam RPZ TWP Gili Matra (halaman 86-88 berkas pdf), menunjukkan bahwa semua kegiatan belum memiliki tujuan yang SMART. Pada halaman 83 berkas pdf dicantumkan sasaran pengelolaan, tetapi sasaran tersebut sama sekali tidak relevan karena yang dinyatakan sebagai sasaran adalah para pemangku kepentingan, seperti antara lain, masyarakat, kelompok masyarakat, LSM dan pemerintah daerah setempat. Lebih jauh lagi, semua kegiatan juga tidak menunjukkan hubungan yang jelas dengan strategi yang memayunginya.

Apakah rencana monitoring kegiatan untuk mencapai sasaran yang telah ditentukan sudah $a d a ?$

Tinjauan terhadap RPZ TWP Gili Matra tidak menemukan sama sekali sebuah rencana monitoring untuk kegiatan-kegiatan yang diusulkan. Hal ini memperkuat asumsi bahwa dokumen tersebut tidak operasional atau tidak dapat langsung diterapkan.

\subsection{Rangkuman Tinjauan Orientasi Efektivitas Pengelolaan}

Hasil tinjauan pada sub-bab sebelumnya dengan jelas menunjukkan bahwa RPZ TWP Gili Matra belum menunjukkan orientasi terhadap efektivitas pengelolaan; diperlukan beragam data dan informasi, serta analisis, tambahan untuk memastikan ia bisa dikatakan berorientasi efektivitas pengelolaan secara penuh.

Dari perspektif Standar Terbuka, maka model konsep Analisis Situasi sementara yang dapat dibangun untuk RPZ TWP Gili Matra berdasarkan data dan informasi terbatas yang tersedia saat ini, disajikan pada Gambar 4. Seperti yang dapat dilihat, masih banyak hal-hal yang harus dijawab agar model konsep yang mencerminkan situasi TWP Gili Matra secara 
komprehensif dapat dibangun. Selain perlu mempertajam dan menerjemahkan sebagian isi RPZ agar sesuai dengan persyaratan efektivitas pengelolaan, ada tiga hal yang juga perlu digali lebih dalam. Pertama hubungan antara strategi pengelolaan dan penataan zonasi dengan permasalahan pengelolaan sebagai cerminan dari ancaman langsung. Kedua, hubungan antara strategi pengelolaan dan penataan zonasi dengan potensi sosial budaya sebagai cerminan dari ancaman tak-langsung. Dan, ketiga, hubungan antara strategi pengelolaan dan penataan zonasi sendiri (lihat pembahasan pada sub-bab 3.2 di atas).

Untuk memfasilitasi tinjauan terhadap RPZ kawasan-kawasan konservasi perairan, pesisir dan pulau-pulau kecil lainnya, penulis menyiapkan sebuah kamus sederhana (Tabel 9) yang menampilkan daftar penamaan pada RPZ dan penamaan yang dinilai sesuai pada Standar Terbuka. Diharapkan dengan menerapkan kamus tersebut para peninjau akan lebih mudah untuk mengidentifikasi semua persyaratan yang sesuai dengan Standar Terbuka, sebelum kemudian memperbaiki RPZ berdasarkan kesenjangan persyaratan yang diidentifikasi kemudian.

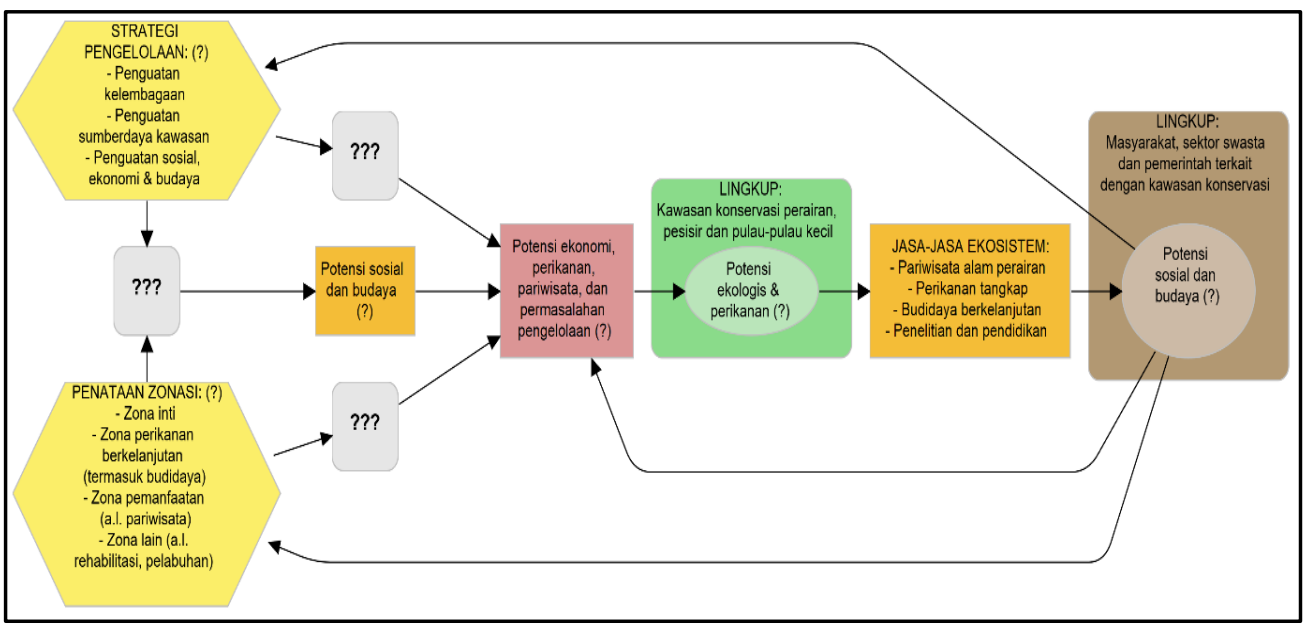

Gambar 4 Diagram Model Konsep Analisis Situasi untuk Rencana Pengelolaan dan Zonasi (RPZ)Taman Wisata Perairan Gili Matra; dibangun menggunakan piranti-lunak Miradi, dan data \& informasi terbatas yang tersedia pada dokumen RPZ.

Tabel 9. Kamus sederhana untuk meninjau isi RPZ dengan menggunakan komponen-komponen Standar Terbuka agar sesuai menjadi RP berorientasi efektivitas pengelolaan

\begin{tabular}{lll}
\hline $\begin{array}{c}\text { Penamaan pada } \\
\text { Standar Terbuka }\end{array}$ & $\begin{array}{c}\text { Penamaan pada } \\
\text { RPZ }\end{array}$ & \multicolumn{1}{c}{ Catatan } \\
\hline Target konservasi & Potensi ekologi & $\begin{array}{l}\text { Ini hanya pendekat (proxy) saja, perlu didalami } \\
\text { lebih lanjut agar dapat diidentifikasi target } \\
\text { konservasi yang definitif mewakili kawasan } \\
\text { secara keseluruhan, serta jasa ekosistem dan } \\
\text { penerima manfaat yang sesuai. }\end{array}$ \\
& & $\begin{array}{l}\text { Ini hanya pendekatan (proxy) saja, perlu } \\
\text { didalami lebih lanjut agar dapat diidentifikasi } \\
\text { ancaman langsung yang dapat diprioritisasi }\end{array}$ \\
\hline langsung & Potensi ekonomi & \\
& \& permasalahan &
\end{tabular}


berdasarkan persyaratan yang disarankan oleh

Standar Terbuka; permasalahan pengelolaan perlu dipertajam agar fokus terhadap target konservasi.

\begin{tabular}{lll}
\hline $\begin{array}{l}\text { Ancaman tak- } \\
\text { langsung }\end{array}$ & $\begin{array}{l}\text { Potensi sosial \& } \\
\text { budaya, dan } \\
\text { permasalahan } \\
\text { pengelolaan }\end{array}$ & $\begin{array}{l}\text { Ini hanya pendekatan (proxy) saja, perlu } \\
\text { didalami lebih lanjut agar dapat diidentifikasi } \\
\text { hubungan sebab akibat yang sesuai dan logis } \\
\text { antara ancaman tak-langsung dengan } \\
\text { ancaman langsung (dengan menggunakan } \\
\text { data dan informasi yang sesuai); permasalahan } \\
\text { pengelolaan perlu dipertajam agar fokus } \\
\text { terhadap target konservasi. }\end{array}$ \\
& Strategi pengelolaan dapat tetap mengacu \\
& kepada pasal 6 Permen KP 30/2010 tetapi \\
& sangat direkomendasikan hanya fokus kepada \\
Strategi & strategi yang terkait dengan pengelolaan \\
& sumberdaya kawasan dan sosial, ekonomi, \& \\
& budaya, yang dapat mengurangi ancaman tak- \\
& langsung dan langsung terhadap target \\
& konservasi. \\
\hline Tindakan & Tindakan pengelolaan dapat tetap mengacu \\
kengelolaan & kepada daftar program pada pasal 7 Permen \\
& KP 30/2010 tetapi sangat direkomendasikan \\
& untuk dimulai dari daftar tindakan yang \\
& paling realistis untuk mengurangi ancaman \\
& tak-langsung dan langsung terhadap target \\
& konservasi. \\
\hline &
\end{tabular}

\section{Kesimpulan dan Saran}

Tujuan akhir (ultimate goal) dari pengembangan kawasan konservasi perairan, pesisir dan pulau-pulau kecil adalah terlestarikannya keanekaragaman dan sumberdaya hayati terbarukan yang dapat membangkitkan manfaat sosial-ekonomi kawasan bagi para pemangku kepentingannya secara berkesinambungan. Untuk mencapai tujuan akhir tersebut, dibutuhkan RP berorientasi efektivitas pengelolaan disamping sumberdaya manusia yang mumpuni dan pendanaan yang cukup.

Kajian yang dipaparkan dalam makalah ini menyampaikan empat persyaratan agar sebuah RP dapat disebut berorientasi efektivitas pengelolaan, yaitu (1) daftar keanekaragaman dan sumberdaya hayati terbarukan yang terancam oleh kegiatan manusia; (2) kegiatan-kegiatan manusia yang secara langsung dan tak-langsung mengancam keberlanjutan keanekaragaman dan sumberdaya hayati; (3) strategi untuk menangani kegiatan-kegiatan manusia yang mengancam keanekaragaman dan sumberdaya hayati; dan (4) tujuan dan sasaran pengelolaan kawasan yang dinyatakan dengan jelas dan terukur. Hasil tinjauan menunjukkan bahwa RPZ TWP Gili Matra yang dijadikan sebagai studi kasus belum dapat disebut telah berorientasi efektivitas pengelolaan. Mengacu kepada persyaratan 
di atas, hanya sebagian kecil isi dari RPZ yang telah memenuhi persyaratan, dan diperlukan perbaikan dan revisi menyeluruh agar ia dapat disebut berorientasi efektivitas pengelolaan secara penuh. Tinjauan menunjukkan bahwa RPZ yang telah disusun tampaknya kesulitan membingkai (framing) persoalan dan tantangan pengelolaan yang dihadapi oleh sebuah TWP sehingga dari segi penerapanpun ia tidak operasional atau dapat dengan segera digunakan oleh unit pengelola kawasan untuk melaksanakan pengelolaan. Ada tiga hal yang menjadi kendala bagi RPZ TWP Gili Matra, yaitu (1) tidak jelasnya hubungan antara strategi \& kegiatan dengan ancaman-ancaman langsung dan tak-langsung yang akan ditangani untuk mengurangi tekanan terhadap target konservasi; (2) tidak adanya tujuan dan sasaran SMART yang disematkan kepada setiap strategi dan kegiatan yang telah dipilih; dan (3) tidak berkorelasinya strategi pengelolaan dengan penataan zonasi.

Ke masa depan, sangat direkomendasikan agar penyusunan semua RPZ sudah berorientasi efektivitas pengelolaan sejak awal. Disamping menggunakan empat persyaratan yang telah disinggung sebelumnya, sangat disarankan untuk menggunakan Standar Terbuka untuk Praktik Konservasi (OSPC) dalam menyusun RPZ. Di masa mendatang, setiap RPZ perlu dilengkapi dengan pemodelan diagramatik yang dibangun dengan menggunakan piranti-lunak Miradi, untuk menunjukkan (i) situasi termutakhir yang dapat disesuaikan dengan dinamika sosial-ekonomi dan sosial-politik yang mempengaruhi kawasan konservasi dan praktik pengelolaannya; dan (ii) teori perubahan (Theory of Change) yang dapat digunakan oleh Badan Pengelola dan para pemangku kepentingan untuk memfasilitasi pencapaian tujuan dan sasaran pengelolaan sekaligus meningkatkan kinerja dan efektivitas pengelolaan. Mengingat semua RPZ kawasan-kawasan konservasi perairan, pesisir dan pulau-pulau kecil yang berada di bawah yurisdiksi Kementerian Kelautan dan Perikanan memiliki daftar isi dan uraian setiap bab yang relatif sama, dan berdasarkan pengalaman meninjau RPZ TWP Gili Matra, sangat disarankan untuk meninjau-ulang dan merevisi semua RPZ tersebut agar mereka menjadi berorientasi efektivitas pengelolaan secara penuh.

Untuk memandu penyusunan RPZ berorientasi efektivitas pengelolaan, penulis mengusulkan daftar isi RPZ seperti yang dicantumkan pada Tabel 10 di bawah ini.

Tabel 10. Daftar isi dan rincian setiap bab yang disarankan untuk RPZ berorientasi efektivitas pengelolaan

\begin{tabular}{cclc}
\hline Bab & \multicolumn{1}{c}{ Judul Bab } & \multicolumn{1}{c}{ Rincian Isi Bab } \\
\hline & Ringkasan Eksekutif & - & Rangkuman tentang RPZ. \\
& & - & Pernyataan efektivitas pengelolaan sesuai dengan jenis \\
& & kawasan konservasi laut. \\
\hline 1 & Pendahuluan & - & Latar belakang dan rasionalisasi penyusunan RPZ. \\
& & - & Tujuan dokumen RPZ. \\
& Potensi dan & - & Potensi ekologi berdasarkan species dan/atau ekosistem \\
& tantangan & penting dan identifikasi target konservasi. \\
& pengelolaan & - Potensi ekonomi dan identifikasi kegiatan pemanfaatan \\
& & yang berpotensi mengancam secara langsung keberlanjutan \\
& & target konservasi, dan pemilihan ancaman langsung. \\
& & - Potensi sosial budaya dan identifikasi kegiatan terkait \\
& & (masyarakat adat, kebijakan) sebagai ancaman tak-langsung \\
& & yang menyumbang kepada terjadinya ancaman langsung.
\end{tabular}




\begin{tabular}{|c|c|c|}
\hline & & $\begin{array}{l}\text { - Analisis situasi dan sintesis untuk memilih dan } \\
\text { menyatakan problem menggunakan diagram Model Konsep } \\
\text { Standar Terbuka. }\end{array}$ \\
\hline 3 & Penataan zonasi & $\begin{array}{l}\text { Penyajian zona-zona yang didirikan untuk menangani } \\
\text { problem yang dinyatakan pada bab sebelumnya. } \\
\text { - Tujuan masing-masing zona yang didirikan berdasarkan } \\
\text { (i) peruntukan (termasuk kegiatan-kegiatan yang boleh dan } \\
\text { tidak boleh dilakukan dalam zona, serta kegiatan yang } \\
\text { memerlukan izin); dan (ii) indikator ekologi berdasarkan } \\
\text { target-target konservasi yang relevan dengan peruntukan } \\
\text { zona. }\end{array}$ \\
\hline 4 & $\begin{array}{l}\text { Rencana Pengelolaan } \\
\text { berbasis zona yang } \\
\text { didirikan }\end{array}$ & $\begin{array}{l}\text { - Strategi umum untuk menangani problem ancaman } \\
\text { langsung dan tak-langsung terhadap target konservasi, } \\
\text { termasuk pernyataan tujuan dan sasaran pengelolaan. } \\
\text { - Strategi tertaut zona untuk menangani problem } \\
\text { ancaman langsung dan tak-langsung terhadap target } \\
\text { konservasi di masing-masing zona, termasuk pernyataan } \\
\text { tujuan dan sasaran pengelolaan. }\end{array}$ \\
\hline \multirow[t]{3}{*}{5} & $\begin{array}{l}\text { Rencana Pengelolaan } \\
\text { tahunan (maksimum } 2 \\
\text { tahun) }\end{array}$ & $\begin{array}{l}\text { - Strategi umum untuk menangani problem ancaman } \\
\text { langsung dan tak-langsung terhadap target konservasi, } \\
\text { termasuk pernyataan tujuan dan sasaran pengelolaan. } \\
\text { - } \quad \text { Rencana monitoring kegiatan dan target konservasi } \\
\text { dalam kawasan secara umum. } \\
\text { - Strategi tertaut zona untuk menangani problem } \\
\text { ancaman langsung dan tak-langsung terhadap target } \\
\text { konservasi, termasuk pernyataan tujuan dan sasaran } \\
\text { pengelolaan. } \\
\text { - Rencana monitoring kegiatan dan target konservasi di } \\
\text { setiap zona. }\end{array}$ \\
\hline & Daftar pustaka & $\begin{array}{l}\text { Daftar semua kepustakaan yang diacu untuk menyusun } \\
\text { dokumen RP. }\end{array}$ \\
\hline & Lampiran & $\begin{array}{l}\text { - Rencana pengelolaan jangka menengah selama } 5 \text { (lima) } \\
\text { tahun. } \\
\text { - Rencana pengelolaan jangka panjang selama } 20 \text { (dua } \\
\text { puluh) tahun. }\end{array}$ \\
\hline
\end{tabular}

\section{DAFTAR PUSTAKA}

Adamcik, R.S., Bellantoni, E.S., DeLong, D.C., Jr., Schomaker, J.H., Hamilton, D.B., Laubhan, M.K. \& Schroeder, R.L. (2004). Writing Refuge Management Goals and Objectives: A Handbook. Washington, DC: US Department of Interior, Fish \& Wildlife Service.

Addison, P. F. E., Collins, D. J., Trebilco, R., Howe, S., Bax, N., Hedge, P., et al. (2018). A new wave of marine evidence-based management: emerging challenges and solutions to transform monitoring, evaluating, and reporting. ICES Journal of Marine Science, 75(3): 941-952. DOI: 10.1093/icesjms/fsx216

Alogan, G.B. \& Yetis, N. (2006). Defining strategic objectives: A methodology suited for public organizations. Total Quality Management \& Business Excellence, 17(6): 669-684. DOI: $10.1080 / 14783360600594172$ 
Arthington, A.H., Dulvy, N.K., Gladstone, W. \& Winfield, I.J. (2016). Fish conservation in freshwater and marine realms: status, threats, and management. Aquatic Conservation: Marine and Freshwater Ecosystems, 26: 838-857. DOI: 10.1002/aqc.2712

Barrios-Garrido, H.A. (2018). Socio-economic drivers affecting marine turtle conservation status: causes and consequences. PhD Thesis. Townsville: James Cook University. Dapat diakses melalui https://doi.org/10.25903/5beofecec8548.

Bradley, B.W., Ronnback, O., Kovacs, J.M., Crona, B., Hussain, S.A., Badola, R., et al. (2008). Ethnobiology, socio-economics and management of mangrove forests: A review. Aquatic Botany, 89: 220-236. DOI: 10.1016/j.aquabot.2008.02.009

Budzich-Tabor, U., Burch, M. \& da Silva, S.G. (2014). Fisheries Areas Network (FARNET) Guide \#9: Fisheries and Tourism, Creating benefits for the community. Brussels: European Commission, FARNET Support unit.

Burke, L., Reytar, K., Spalding, M. \& Perry, A. (2011). Reefs at Risk Revisited. Washington, DC: World Resources Institute.

Conservation Measures Partnership (2020). Open Standards for the Practice of Conservation, version 4.0. Conservation Measures Partnership (www.conservationmeasures.org).

Cullen-Unsworth, L. \& Unsworth, R. (2013). Seagrass Meadows, Ecosystem Services, and Sustainability. Environment: Science and Policy for Sustainable Development, 55(3): 14-28. DOI: 10.1080/00139157.2013.785864

Day, J. C., Laffoley, D. \& Zischka, K. (2015). Marine protected area management. In Worboys, G. L., Lockwood, M., Kothari, A., Feary, S. \& Pulsford, I. (eds.) Protected Area Governance and Management. Canberra: ANU Press, pp. 609-650.

Davies, R. (2013). Planning Evaluability Assessment: A Synthesis of the Literature with Recommendations. Report of a study commissioned by the Department of International Development. London (UK): DFID.

Dudley, N. (editor) (2008). Guidelines for Applying Protected Area Management Categories. Gland (Switzerland): IUCN.

FAO (2009). Report of the FAO/UNEP Expert Meeting on Impacts of Destructive Fishing Practices, Unsustainable Fishing, and Illegal, Unreported and Unregulated (IUU) Fishing on Marine Biodiversity and Habitats. Rome, 23-25 September 2009. Rome: Food and Agriculture Organization of the United Nations.

Hamann, M., Godfrey, M.H., Seminoff, J.A., Arthur, K., Barata, P.C.R., Bjorndal, K.A., et al. (2010). Global research priorities for sea turtles: informing management and conservation in the 21st century. Endangered Species Research, 11:245-269. DOI: 10.3354/esro0279

Hiscock, K. (1998). Biological monitoring of marine Special Areas of Conservation: a review of methods for detecting change (JNCC Report No. 284). Peterborough (UK): Joint Nature Conservation Committee.

Hockings, M., Stolton, S. \& Dudley, N. (2000). Evaluating effectiveness: a framework for assessing the management of protected areas. Gland (Switzerland) and Cambridge (UK): IUCN.

Hockings, M., Stolton, S., Leverington, F., Dudley, N. \& Courrau, J. (2006). Evaluating effectiveness: a framework for assessing management effectiveness of protected areas, second edition. Gland (Switzerland) \& Cambridge (UK): IUCN.

Holmlund, C.M. \& Hammer, M. (1999). Ecosystem services generated by fish populations. Ecological Economics, 29: 253-268. 
Jani, J.M., Jamalludin, M.A. \& Long, S.L. (2020). To Ban or Not to Ban? Reviewing an Ongoing Dilemma on Sea Turtle Egg Trade in Terengganu, Malaysia. Frontiers in Marine Science, 6: 762. DOI: 10.3389/fmars.2019.00762

Kapos, V., Balmford, A., Aveling, R., Bubb, P., Carey, P., Entwistle, A., et al. (2008). Calibrating conservation: new tools for measuring success. Conservation Letter, 1: 155164. DOI: $10.1111 / \mathrm{j} .1755-263 X .2008 .00025 . \mathrm{x}$

Kapos, V., Balmford, A., Aveling, R., Bubb, P., Carey, P., Entwistle, A., et al. (2009). Outcomes, not implementation, predict conservation success. Oryx, 43(3): 336-342. DOI: 10.1017/S0030605309990275

Kelleher, G. (1999). Guidelines for Marine Protected Areas. Gland (Switzerland) \& Cambridge (UK): IUCN.

Lachs, L. \& Onate-Casado, J. (2020). Fisheries and tourism: social, economic, and ecological trade-offs in coral reef systems. In Jungblut S., Liebich V., Bode-Dalby M. (eds) TOUMARES 9 - The Oceans: Our Research, Our Future. Cham (Switzerland): Springer, pp. 243 - 260.

Longhurst, R., Wichmand, P. \& Perrin, B. (2016). Building Evaluability Assessments into Institutional Monitoring and Evaluation (MङEE) Frameworks. Centre for Development Impact (CD) Practice Paper No. 17. Brighton (UK): Institute of Development Studies.

Mancini, A., Senko, J., Borquez-Reyes, R., Póo, J.G., Seminoff, J.A. \& Koch, V. (2011). To Poach or Not to Poach an Endangered Species: Elucidating the Economic and Social Drivers Behind Illegal Sea Turtle Hunting in Baja California Sur, Mexico. Human Ecology, 39: 743-756. DOI: 10.1007/s10745-011-9425-8

Margoluis, R. \& Salafsky, N. (2001). Is our project succeeding? A guide to Threat Reduction Assessment for conservation. Washington, DC: Biodiversity Support Program.

Mascia, M.B., Fox, H.E., Glew, L., Ahmadia, G.N., Agrawal, A., Barnes, M., et al. (2017). A novel framework for analyzing conservation impacts: evaluation, theory, and marine protected areas. Annals of the New York Academy of Sciences, 1399: 93-115. DOI: 10.1111 /nyas. 13428

Meneghello, S. \& Mingotto, E. (2016). Promoting Sustainable Development through Fisheriesrelated Tourism Experiences: Benefits from the Integration between Fisheries and Tourism in Venetian Coastal Areas. International Journal of Sustainable Development and Planning, 11 (3): 447-457. DOI: 10.2495/SDP-V11-N3-447-457

Mitra, A. (2020). Ecosystem Services of Mangroves: An Overview. In: Mangrove Forests in India. Cham (Switzerland): Springer Nature. Doi: 10.1007/978-3-030-20595-9_1

MMMPA Supervisory Board (2016). Monitoring Mediterranean Marine Protected Areas: A set of guidelines to support the development of management plans (Deliverable of the MMMPA European project (FP7-PEOPLE-2011-ITN g.a. no.: 290056). Ancona (Italy): Reef Check Italia onlus.

Muñoz, D.M. (2018). Contribution to the concepts of fishing tourism and pesca-tourism. Cuadernos de Turismo, 42: $655-657$.

Neo, M.L., Eckman, W., Vicentuan, K., Teo, Serena L.-M. \& Todd, P.A. (2015). The ecological significance of giant clams in coral reefecosystems. Biological Conservation, 181: 111-123. DOI: 10.1016/j.biocon.2014.11.004

Neo, M.L., Wabnitz, C.C.C., Braley, R.D., Heslinga, G.A., Fauvelot, C., van Wynsberge, S., et al. (2017). Giant clams (Bivalvia: Cardiidae: Tridacninae): a comprehensive update of 
species and their distribution, current threats and conservation status. Oceanography and Marine Biology: An Annual Review, 55: 87-388.

Peraturan Menteri Kelautan dan Perikanan Nomor 30 Tahun 2010 tentang Rencana Pengelolaan dan Zonasi Kawasan Konservasi Perairan.

Piasecki, W., Głąbiński, Z., Francour, P., Koper, P., Saba, G., Molina, G.A. et al. (2016). Pescatourism - A European review and perspective. Acta Ichthyologica et Piscatoria, 46(4): 325-350. DOI: 10.3750/AIP2016.46.4.06

Piet, G.J., van Overzee, H.M.J., Miller, D.C.M. \& Gelabert, E.R. (2017). Indicators of the 'wild seafood' provisioning ecosystem service based on the surplus production of commercial fish stocks. Ecological Indicators, 72: 194-202. DOI: 10.1016/j.ecolind.2016.08.003

Rusandi, A. (2020). Pengelolaan Kawasan Konservasi. Presentasi disampaikan pada Online Lesson Learn 2020 “Ada Apa Dengan Konservasi Laut di Indonesia.” Video conference, 20 Mei 2020.

Salafsky, N. \& Margoluis, R. (1999). Threat reduction assessment: a practical and cost-effective approach to evaluating conservation and development projects. Conservation Biology, 13(4): 830-841.

Salm, R.V., Clark, J. \& Siirila, E. (2000). Marine and Coastal Protected Areas: A guide for planners and managers. Gland (Switzerland) \& Cambridge (UK): IUCN.

Short, F.T., Polidoro, B., Livingstone, S.R., Carpenter, K.E., Bujang, J.S., Calumpong, H.P., et al. (2011). Extinction risk assessment of the world's seagrass species. Biological Conservation, 144: 1961-1971. DOI: 10.1016/j.biocon.2011.04.010

Surat Keputusan Menteri Kelautan dan Perikanan Nomor 57 Tahun 2014 tentang Rencana Pengelolaan dan Zonasi Taman Wisata Perairan Pulau Gili Ayer, Gili Meno dan Gili Trawangan di Provinsi Nusa Tenggara Barat Tahun 2014-2034

Soemodinoto, A., Yulianto, I., Kartawijaya, T., Herdiana, Y., Ningtias, P., Kassem, K.R. \& Andayani, N. (2018). Contribution of local governments to a national commitment of the Aichi Biodiversity Target 11: the case of West Nusa Tenggara Province, Indonesia. Biodiversity, 19(1-2): 72-80. DOI: 10.1080/14888386.2018.1467790

Teelucksingh, S.S., Eckert, S. \& Nunes, Paulo A.L.D. (2010). Marine Turtles, Ecosystem Services and Human Welfare in the Marine Ecosystems of the Caribbean Sea: A Discussion $\begin{array}{llll}\text { of Key Methodologies. Études } & 15\end{array}$ (http://etudescaribeennes.revues.org/4399).

Thomas, L. \& Middleton, J. (2003). Guidelines for Management Planning of Protected Areas. Gland (Switzerland) \& Cambridge (UK): IUCN.

Trevisan, M.S. \& Walser, T.M. (2015). Evaluability assessment: improving evaluation quality and use. Thousand Oaks (California): Sage.

UNEP (2006). Marine and coastal ecosystems and human wellbeing: A synthesis report based on the findings of the Millennium Ecosystem Assessment. Nairobi (Kenya): United Nations Environment Programme.

Unsworth, R.K.F., McKenzie, L.J., Collier, C.J., Cullen-Unsworth, L.C., Duarte, C.M., Eklof, J.S., et al. (2019). Global challenges for seagrass conservation. Ambio, 48: 801-815. DOI: 10.1007/s13280-018-1115-y

Uraidi, N. \& Kumar, V. (2016). Strategic Objectives. In Augier, M. \& Teece, D.J. (eds.) The Palgrave Encyclopedia of Strategic Management, 4 pp. DOI: 10.1057/978-1-349-948482_277-1 
Webber, M., Calumpong, H., Ferreira, B., Granek, E., Green, S., Ruwa, R. \& Soares, M. (2016). Chapter 48. Mangrove. In: The First Global Integrated Marine Assessment, World Ocean Assessment I. New York: United Nations.

Wilkinson, C. (2008). Status of coral reefs of the world: 2008. Townsville (Australia): Global Coral Reef Monitoring Network and Reef and Rainforest Research Centre.

Woodhead, A.J., Hicks, C.C., Norström, A.V., Williams, G.J. \& Graham, N.A.J. (2019). Coral reef ecosystem services in the Anthropocene. Functional Ecology, 33: 1023-1034. DOI: $10.1111 / 1365-2435.13331$ 